This item was submitted to Loughborough's Research Repository by the author.

Items in Figshare are protected by copyright, with all rights reserved, unless otherwise indicated.

\title{
UK microgeneration. Part II: technology overviews
}

PLEASE CITE THE PUBLISHED VERSION

http://dx.doi.org/10.160/ener.2010.163.4.143

PUBLISHER

(C) ICE Publishing Ltd.

VERSION

VoR (Version of Record)

LICENCE

CC BY-NC-ND 4.0

REPOSITORY RECORD

Staffell, lain, Philip Baker, John P. Barton, Noam Bergman, Richard E. Blanchard, Nigel P. Brandon, Daniel J.L. Brett, et al.. 2019. "UK Microgeneration. Part II: Technology Overviews". figshare.

https://hdl.handle.net/2134/11765. 
This item was submitted to Loughborough's Institutional Repository (https://dspace.lboro.ac.uk/) by the author and is made available under the following Creative Commons Licence conditions.

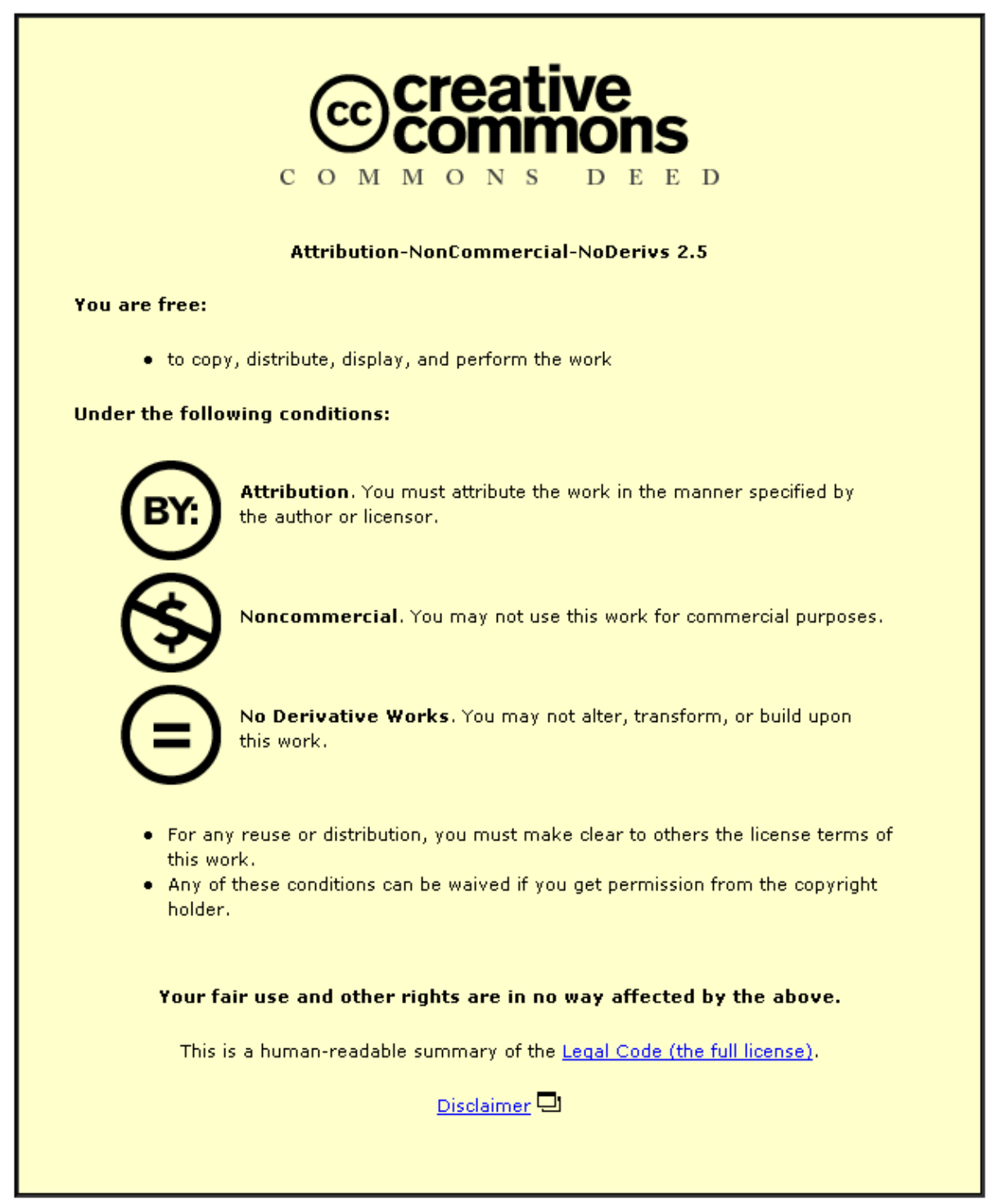

For the full text of this licence, please go to: http://creativecommons.org/licenses/by-nc-nd/2.5/ 


Proceedings of the Institution of
Civil Engineers
Energy 163
November 2010 Issue EN4
Pages $143-165$
doi: $10.1680 /$ ener.2010.163.4.143
Paper 900038
Received 28/09/2009
Accepted 07/12/2009
Keywords:
energy conservation/renewable
energy/reviews
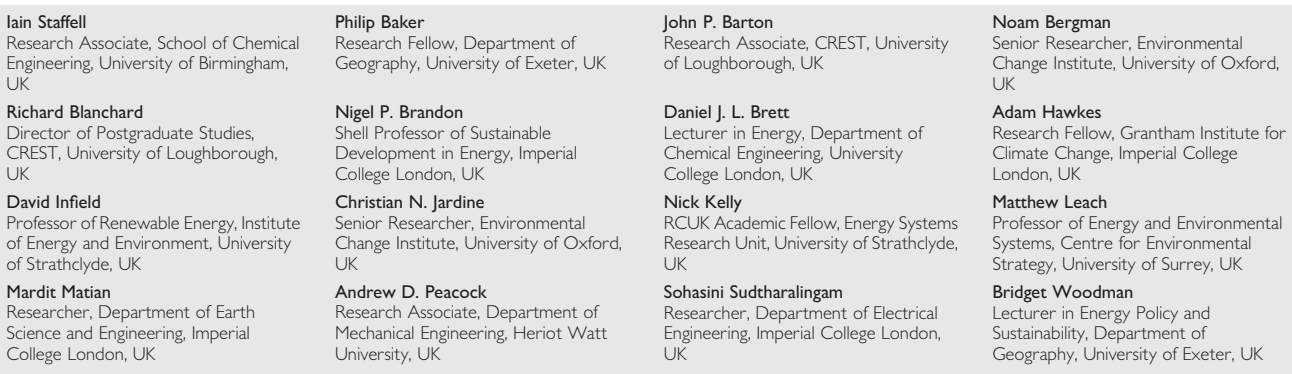

\section{UK microgeneration. Part II: technology overviews}

I. Staffell MSc, P. Baker MSc, PhD, J. P. Barton MSc, MA(Cantab)., PhD, N. Bergman PhD, R. Blanchard PhD, N. P. Brandon PhD, FREng, D. J. L. Brett PhD, DIC, A. Hawkes PhD, D. Infield PhD, CPhys, MlnstP, BWEA, C. N. Jardine DPhil, MChem, N. Kelly PhD, M. Leach PhD, DIC, CEng, FEl, FRSA, M. Matian MSc, PhD, A. D. Peacock, S. Sudtharalingam MEng, PhD and B. Woodman PhD

This paper reviews the current status of microgeneration technologies at the domestic scale. Overviews are given for nine such technologies, grouped into three sections: (a) low carbon heating: condensing boilers, biomass boilers and room heaters, air source and ground source heat pumps; (b) renewables: solar photovoltaic panels, flat plate and evacuated tube solar thermal panels and micro-wind; and (c) combined heat and power: Stirling engines, internal combustion engines and fuel cells. Reviews of the construction, operation and performance are given for the leading commercial products of each technology. Wherever possible, data are presented from the field, giving the actual prices paid by customers, efficiencies and energy yields experienced in real-world use, reliability and durability, and the problems faced by users. This information has a UK focus but is generally relevant in the international context. Two issues are found to be prevalent throughout the microgeneration industry. Total installed costs are a premium and vary substantially between technologies, between specific products (e.g. different models of solar panel), and between individual installations. Performance in the field is found in many cases to differ widely from manufacturers' quotes and laboratory studies, often owing to installation and operational problems. Despite this, microgeneration has demonstrated substantial improvements over conventional generation in terms of fossil fuel consumption, carbon dioxide emissions and energy cost, provided that the appropriate technologies are employed, being installed and operated correctly according to the load requirements of the house and their physical location.

\section{INTRODUCTION}

Microgeneration is the generation of zero or low-carbon heat and/or power by individuals, small businesses and communities to meet their own needs. There is a wealth of microgeneration technologies either commercially available or at an advanced stage of development, as summarised in Table 1.

Microgeneration is an important part of many countries' energy strategy, since it is seen as a way to improve energy security by reducing fuel imports and to reduce carbon dioxide emissions from energy generation. In this respect, the UK has chosen to follow the $60+$ countries that have introduced a feed-in tariff (FIT) for microgeneration (REN21, 2009). The UK's proposal aims to provide households with a $5-7 \%$ rate of return by paying up to $36.5 \mathrm{p}$ per $\mathrm{kWh}$ of electricity generated, and will provide a guaranteed value for exports back to the electricity network from April 2010 onwards (DECC, 2009). This will be followed by the renewable heat initiative (RHI) in 2011, which similarly aims to reward owners of heat-producing microgeneration with an as-yet undecided payment scheme. These are seen as gamechanging developments in the microgeneration industry, providing the much needed subsidies that will enable wide-scale deployment, and with it the economies of scale required to bring down costs, and an improved public awareness of microgeneration as an energy supply option.

The label of 'microgeneration' refers to a highly diverse set of technologies, which show marked differences in output, cost effectiveness and suitability. Harrison writes that considering microgeneration as a unified group is "particularly unhelpful when attempting to understand the potential contribution [it] can make to UK energy strategy and it is important that we understand the particular characteristics and potential role of each technology' (Harrison, 2008b). This paper therefore aims to highlight the different strengths and weaknesses of each technology with an up-to-date review of their performance and potential, and builds on limited reviews of the technology (Fisher et al., 2008; Future Energy Solutions, 2006; Harrison, 2008b; Onovwiona and Ugursal, 2006) to include data from real-world field trials wherever possible.

This paper is the summary of nine technology reviews commissioned as part of the UK Energy Research Centre (UKERC) cross-theme research project on microgeneration. It is the second in a series of position papers, the first of which addressed the behavioural and policy aspects of microgeneration (Bergman et al., 2009), with a future paper considering finance, carbon dioxide savings, systems modelling, market diffusion and how the technologies can satisfy different energy demand profiles. This paper has a UK focus where appropriate; however, most of the technology-specific information is globally relevant. The costs and performance figures presented in this paper were 


\begin{tabular}{|c|c|c|c|c|c|}
\hline \multirow[t]{2}{*}{ Technology } & \multirow[t]{2}{*}{ Energy conversion process } & \multicolumn{2}{|c|}{ Benefit } & \multicolumn{2}{|c|}{ UK status } \\
\hline & & Renewable & Higher efficiency & Supported & Emerging \\
\hline Condensing boilers & Gas $\rightarrow$ Heat & & & $\checkmark$ & \\
\hline Biomass boilers & Sustainable fuel $\rightarrow$ Heat & $\checkmark$ & & $\checkmark$ & \\
\hline Heat pumps & Electricity + Sun $\rightarrow$ Heat & & $\checkmark$ & $\checkmark$ & \\
\hline Solar photovoltaic & Sun $\rightarrow$ Electricity & $\checkmark$ & & $\checkmark$ & \\
\hline Solar thermal & Sun $\rightarrow$ Heat & $\checkmark$ & & $\checkmark$ & \\
\hline Micro-wind & Sun $^{*} \rightarrow$ Electricity & $\checkmark$ & & $\checkmark$ & \\
\hline Internal combustion engines & Gas $\rightarrow$ Heat + Electricity & & $\checkmark$ & & $\checkmark$ \\
\hline Stirling engines & Gas $\rightarrow$ Heat + Electricity & & $\checkmark$ & & $\checkmark$ \\
\hline Fuel cells & Gas $\rightarrow$ Heat + Electricity & & $\checkmark$ & & $\checkmark$ \\
\hline
\end{tabular}

as recent as could be found at the time of publication, but these are expected to be superseded by new generations of technology that are currently under development.

\section{COMMON FACTORS FOR MICROGENERATION TECHNOLOGIES}

Within the scope of this work, microgeneration is considered at the residential scale, with capacities of less than $3 \mathrm{~kW}$ electrical $\left(\mathrm{kW}_{\mathrm{e}}\right)$ and $30 \mathrm{~kW}$ thermal $\left(\mathrm{kW}_{\mathrm{th}}\right)$. This differs from the standard EU definition of microgeneration being up to $50 \mathrm{~kW}_{\mathrm{e}}$, owing to the focus on single-family households without access to district heating networks (Hawkes et al., 2009). Large-scale renewable projects such as wind farms have very different technology issues, and the economic case for combined heat and power (CHP) in larger residential and commercial buildings (10$50 \mathrm{~kW}_{\mathrm{e}}$ ) is already clear, resulting in a thriving industry within this sector (Kuhn et al., 2008). At the single-family residential scale, the economic and technological case is less well defined. However, these dwellings offer substantially greater potential as they vastly outnumber other types of property, and present the least exploited market for distributed energy technologies.

The following issues are common to most, if not all, microgeneration technologies when installed in the residential sector.

\section{I. Energy conversion, storage and export}

Unlike the electricity grid and gas boiler that homeowners are accustomed to, microgeneration technologies can (and often do) produce heat or power at times when it is not required renewables are reliant on weather patterns and CHP systems have inseparable heat and electricity outputs. Equally, the energy demands from individual homes are highly variable and unpredictable, and do not match the times of day that devices will be producing energy.

In order to maximise the amount of energy supplied, it is therefore beneficial to delineate supply and demand. Electricity is usually exported to the grid where possible, as battery storage is impractical and expensive at present (Hawkes et al., 2009), whereas heat is usually stored locally as hot water, since heat distribution networks are rare in the UK. This prevents excess energy from going to waste, and allows low-capacity heating devices to produce a small but steady amount of heat throughout the day.
2.1.1. Electricity export. Electricity is the highest value form of energy, both economically and in terms of carbon content. The ability to export generated electricity at times when it is not required is therefore vital to maximise the economic and environmental benefits of microgeneration. This requires the installation of an export meter (or smart meter) which measures both the amount of import and export; or net meters, where the meter simply goes in reverse when electricity is exported. The latter is not favoured by power companies as it is less secure and does not allow for price differentiation between import and export.

\subsubsection{Thermal storage. Most manufacturers supply high-} capacity, high-efficiency heat stores which use $50-80 \mathrm{~mm}$ of insulation and are designed to maximise thermal stratification (e.g. Guntamatic, 2007; SolarFocus GmbH, 2008b). Standard hot water cylinders are not always compatible with heat-producing microgeneration technologies, as higher storage temperatures are needed to achieve the same storage capacity, and less insulation results in greater standing losses.

Heat stores typically range from 150 to 750 L (Aki, 2007; Senertec, 2008), around a quarter of which is for 50-200 L of daily hot water consumption (Energy Saving Trust, 2008; Forward et al., 2008; Veitch and Mahkamov, 2009). The majority of the tank is a warm water buffer $\left(\sim 45^{\circ} \mathrm{C}\right)$ that is used as an intermediate heat exchanger between the generator and central heating system. The space required for such a tank poses a problem for installation in smaller houses, so they are often installed in basements, loft areas or outside, where radiated heat losses are not useful towards heating the house. However, the size and improved design of these heat stores over conventional hot water cylinders enables heat generators to increase their performance in general ways.

(a) CHP, heat pumps and boilers can operate for longer hours and reduce on/off cycles as they reheat the tank, improving their efficiency.

(b) Smaller microgeneration capacity can be installed, thus reducing capital cost of the most expensive system component.

(c) CHP and heat pump operation can be shifted to coincide with times of electricity generation (morning/evening) or cheap-rate imported electricity respectively. 
(d) Solar heat can be stored during consecutive dull days, increasing its contribution to space heating.

\subsection{Low-temperature heat}

Lower temperature space heating provides greater efficiency, regardless of the technology employed to produce it. Highefficiency boilers require the output temperature to be below $55^{\circ} \mathrm{C}$ in order to operate in condensing mode (Carbon Trust, 2007), while the efficiency and energy output of other microgeneration technologies drop significantly as output temperature rises, most notably with heat pumps and solar thermal.

A performance improvement can therefore be gained by using large surface-area radiators or under-floor heating, which use water at $30-50^{\circ} \mathrm{C}$ (Energy Saving Trust, 2004). Contrary to general opinion this is not essential though, as most microgeneration can operate adequately with the existing radiators in a house. It is however advised that regular radiators are run at their minimum operating temperature (around $45^{\circ} \mathrm{C}$ ) to minimise performance loss in the generator. The cost of retrofitting a new heating system into existing properties may not be justified by the gains they provide, but they can make economic sense in new-build properties.

Domestic hot water must be periodically raised to $60^{\circ} \mathrm{C}$ before usage owing to the risk posed by Legionnaires disease (Health and Safety Commission, 2000), meaning that lower efficiencies and yields are attained relative to space heating; although methods to minimise these impact have been proposed (Hill, 2009).

\subsection{Equipment sizing}

It is important to choose the right capacity of microgeneration to match heat and power loads of each individual house. The obvious considerations are that smaller systems will have lower capital costs, but will meet a smaller portion of demand meaning greater reliance on backup systems (with higher running costs and carbon dioxide emissions), or an inability to meet peak demands if no backup is present.

Most technologies have a lower efficiency when run at partial load, either because of incomplete fuel combustion or higher ancillary power drains (Beausoleil-Morrison, 2007; Ida, 2008; Thomas, 2008). In systems that cycle on and off rather than modulating output, shorter running cycles are experienced when the system is oversized (Carbon Trust, 2007). The power consumed during start-up and shut-down, and additional fuel required to pre-heat systems contributes to the lower efficiency and higher running costs experienced. This has proven a particular problem for Stirling engines owing to their high thermal output and low electrical efficiency. These can only operate close to rated efficiency in larger houses with sufficient hot water demand in summer (Carbon Trust, 2007).

Microgeneration systems therefore tend to be undersized compared to the peak demands of the house, allowing for longer operating periods at high loads. Owing to the complexity of determining system size, a site survey is usually undertaken by an installer before sale, to determine the heat losses and power consumption in the given property.

\subsection{Real-world performance}

The disparity between performance quoted by manufacturers and that experienced by real customers is an issue for most, if not all, microgeneration technologies. This is understandable to a degree, as manufacturers can be expected to measure their system's performance in controlled laboratory conditions, rather than the varied and often sub-optimal conditions offered by real homes. However, in some cases a gulf exists between laboratory and real-world performance, leading to calls for better regulation of the industry, and public anger at being 'misled' by manufacturers of boilers and other technologies.

It is unjustified to claim that the entire burden of responsibility is on the manufacturers, as installers and users arguably have the greatest influence on the overall performance that can be realised. There is some onus on installers to carefully consider the location and size of microgeneration technologies: a surprising number of solar panels and wind turbines perform well below specification owing to poor siting by installers (Encraft, 2009; Munzinger et al., 2006). Solar panels can end up shaded by other parts of the building or surrounding landscape, and wind turbines are routinely installed in areas with insufficient wind speeds to meet the manufacturer's recommendations.

The way in which a microgeneration system is used will ultimately govern how well it performs. Sub-optimal conditions can be devastating to performance, and often result from choosing an unsuitable technology for the specific house, or simply a lack of basic information given to the owners. Simple actions, such as lowering the temperature of space heating, can have a significant impact on efficiency, with no perceivable loss in room temperature or comfort. Monitoring how well the technology is running (or if it is running at all), and properly configuring any backup heating so as not to interfere, can also have a dramatic effect on the amount of energy delivered.

Microgeneration cannot be treated simply as a black box that will automatically lower cost and emissions - it must be used correctly, which requires an awareness of our own energy habits and behavioural issues (Bergman et al., 2009).

\subsection{Performance assessment}

Also common to all microgeneration technologies are issues surrounding the way their performance is assessed. Typically the economic or environmental performance is assessed relative to an assumed 'baseline' or 'reference' system. This reference system is taken to be the conventional means of meeting energy demands in a residential dwelling - usually defined as a condensing boiler and central electricity generation. The performance assessment is therefore based on an assumption regarding what will not happen owing to the presence of the microgeneration system (e.g. avoided generation in power stations).

It is important to note that this displaced reference system is dynamically evolving, and marginal in nature. Changes occur on the margin of the reference system (e.g. with a particular group of rapid-start power stations) and do not influence all aspects of the system equally. Additionally, this reference system is predicted to undergo rapid change. These two factors cast doubt on any predictions of performance that use a static 
reference system, because economic and environmental parameters in this marginal and dynamic system can be significantly different to those of the average energy system at a specific point in time (Hawkes and Brandon, 2009).

\section{TECHNOLOGY REVIEWS}

\section{I. Low carbon heat}

Low carbon heating has significant potential for reducing both consumers' fuel bills and environmental impacts from the domestic sector, as around 80\% of energy demand from UK homes is for heat (EnergyWatch, 2008; Utley and Shorrock, 2006). By providing a significant portion of this demand from lower carbon sources or with higher efficiency, these heating technologies can contribute annual carbon dioxide savings of 2-3t per household (Harrogate Borough Council, 2007; Mitsubishi Electric, 2008).

\subsubsection{Condensing boilers. Condensing boilers are high-} efficiency gas-fired air or water heaters that were introduced in the early 1980s, and are very similar to the standard hydronic boilers popular throughout Europe. Condensing gas and oil boilers have become mandatory in the UK owing to their improved efficiency, and so these are usually thought of as a reference technology rather than a form of microgeneration. An enlarged or secondary heat exchanger is used to reduce the flue exit temperature from around $150^{\circ} \mathrm{C}$ to $50^{\circ} \mathrm{C}$, extracting around 10\% more energy from the fuel (Energy Saving Trust, 2003).

\subsubsection{Cost. Owing to the relative simplicity of the} technology and scale of manufacture, condensing boilers have the lowest capital cost of the presented heating technologies. The average retail price in the UK is $£ 650-800$ for a typical $24 \mathrm{~kW}_{\text {th }}$ boiler, with an extra $£ 5-20$ per additional $\mathrm{kW}_{\text {th }}$ output (Staffell, 2008). Smaller boilers are available from most manufacturers at a lower cost, but are generally shunned by installers.

Installation of the boiler adds significantly to the cost, as labour-intensive regulations from both the government and boiler manufacturers must be adhered to. The majority of houses require upgrades to their gas and electricity supplies, increasing the fully installed cost to $£ 2000-2500$. (Costs from a survey of local and national installers around Birmingham and London.) This could be expected to drop to around $£ 1500$ in new-build properties, or those that already meet current regulations (Which?, 2007).

\subsubsection{Efficiency. Condensing boilers offer the highest} efficiency of any gas-based heating technology, with manufacturers claiming to attain up to $98 \%$ higher heating value (HHV) (Viessmann, 2007). (All efficiencies are given against higher heating value unless otherwise stated.) Independent verification of boiler efficiencies is publicly available from SEDBUK (Seasonal Efficiency of Domestic Boilers in the UK) whose laboratory tests show seasonal efficiencies of $91.5 \%$ from the best performing boilers (Defra, 2008a). However, preliminary results from two independent field trials of 'A-rated' boilers show that real-world efficiency is 4-5\% lower than in the laboratory, averaging 82-89\% HHV (Carbon Trust, 2007; Orr et al., 2009).

Regular 'system' boilers demonstrated 3\% higher efficiency than 'combi' designs (system boilers use a storage tank for hot water, whereas combination boilers provide hot water and space heating on demand with no storage). However, they were expected to deliver less useful energy owing to estimated 5\% losses in the tank and pipework (Orr et al., 2009). Hot water production was much less efficient, with 15-65\% estimated for regular boilers owing to excessive losses in the cylinder, and $40-80 \%$ for combi boilers, owing to the warm-up lag during short individual draws (e.g. washing hands) (Orr et al., 2009). It was also found that electricity consumption by modern boilers can be significant, averaging $225 \mathrm{kWh}$ per year (Carbon Trust, 2007; Orr et al., 2009). Consumption by different models varied by a factor of 2, mainly owing to the way the boiler was controlled by timers and thermostats (Orr et al., 2009).

3.1.1.3. Durability. The introduction of condensing boilers in the UK has been marred by scepticism and criticism of their reliability (Inman, 2005a, 2005b). The added complexity and use of fragile heat exchangers in early models caused concern, although the technology has since had over 20 years to mature. Current systems are believed to be as reliable as conventional boilers, with lifetimes of 10 to 15 years provided they are serviced annually (Energy Saving Trust, 2003).

Crucially, there have been no conclusive public surveys into the lifetime or reliability of condensing boilers. British Gas holds a private database amassed from their 4 million customers on maintenance contracts, but have given very few comments on their findings (Inman, 2005a). As a result of this grey area, nearly half those surveyed were put off upgrading to a condensing boiler before they had to because of the bad reputation they have (Caird et al., 2008).

\subsubsection{Biomass boilers. Biomass heating systems allow a} sustainable and low-carbon fuel to be utilised for domestic heating. (Biomass fuel must be sourced from sustainably managed forests for these benefits to be valid; however, as the felling of trees in the UK is strictly regulated by the Forestry Commission, good management practices can be expected (Ireland et al., 2006).) This can be grown locally, providing energy self-sufficiency and domestic employment.

Microgeneration options for biomass include traditional open fires, wood-burning stoves (e.g. $5 \mathrm{~kW}_{\text {th }}$ space heaters), and complete boilers $\left(10-20 \mathrm{~kW}_{\mathrm{th}}\right)$ that are connected to hot water or central heating systems. Boilers are floor mounted, occupying a minimum footprint of $1 \mathrm{~m}^{2}$ by $1.5 \mathrm{~m}$ high, whereas room heaters are smaller but require a thermally insulating platform. A flue or vent for post combustion gases is required to adhere to building regulations and clean air legislation. Table 2 summarises the typical characteristics of these systems with different fuels.

Solid biomass in the form of wood is utilised for microgeneration but other woody material such as Miscanthus (elephant grass) can be utilised. Sources of fuel include dedicated short rotation coppice (SRC) and wastes from the timber industry, which are processed into the form of logs or pellets for ease of delivery, storage, and loading. Logs are the cheapest form available, but are the least convenient as they have low energy density and require manual loading. Wood chips are also available cheaply, but require a prohibitive amount of storage space owing to their low density. Pellets are formed from compressed sawdust (sawmill waste), and are ideal 


\begin{tabular}{|c|c|c|c|c|c|}
\hline \multirow[t]{2}{*}{ Type of fuel } & \multirow{2}{*}{$\frac{\text { Open fire }}{\log }$} & \multicolumn{2}{|c|}{ Room heater } & \multicolumn{2}{|c|}{ Boiler } \\
\hline & & Log & Pellet & Log & Pellet \\
\hline Automatic fuel feed & & & $\checkmark$ & & $\checkmark$ \\
\hline Automatic air delivery & & & $\checkmark$ & $\checkmark$ & $\checkmark$ \\
\hline Connected to hot water and radiator system & & & & $\checkmark$ & $\checkmark$ \\
\hline Electricity required for combustion fan and control system & & & $\checkmark$ & $\checkmark$ & $\checkmark$ \\
\hline Range of efficiency & $10-30 \%$ & $\sim 70 \%$ & $\sim 80 \%$ & $\sim 80 \%$ & $\sim 90 \%$ \\
\hline
\end{tabular}

for automatic loading into a domestic system as they are uniform and cylindrical.

Biomass boilers have a strict tolerance on the moisture content of wood burnt, as water released during burning lowers efficiency, increases emissions, and can damage the burner and flues. Initial problems when switching to biomass are often related to fuel quality and moisture content (South West of England Regional Development Agency, 2008). Wood is typically felled with 25-30\% moisture content, and so must be dried to around $10 \%$ to be suitable for typical boilers. It will typically take two seasons of storage before the wood is dry enough to burn.

A typical domestic property requires 3-5t of wood per year, although this can be delivered at regular times during the heating season (Biomass Energy Centre, 2008, 2009). A hopper of around $1 \times 2 \times 3 \mathrm{~m}$ would be required to store a year's worth of pellets, which restricts suitability to larger homes (see Figure 1), but allows for cheaper, bulk deliveries.

3.1.2.1. Cost. High initial costs are the main factor hindering uptake. Various surveys place the average installed cost of a $15 \mathrm{~kW}_{\text {th }}$ biomass boiler at between $£ 5000$ and $£ 15000$ (Bergman and Jardine, 2009; BERR, 2009b; Energy Saving Trust, 2005; National House Building Confederation Foundation, 2008). These systems are therefore anticipated initially to target offgrid properties that currently use oil or electricity for heating. Standalone room heaters of around $6 \mathrm{~kW}_{\text {th }}$ are, however, significantly less expensive, costing £2000-4000 (BERR, 2009b).

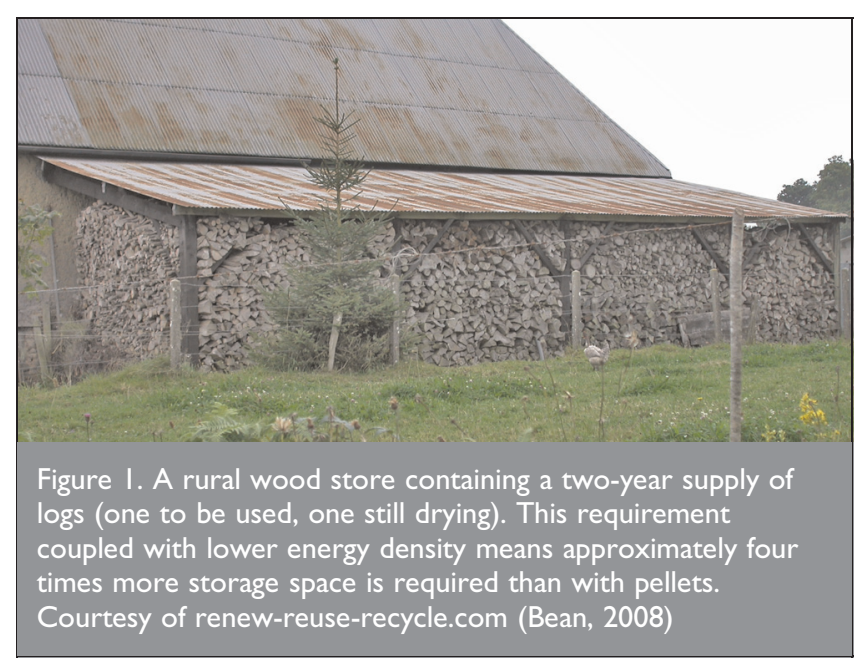

Support is available in the form of grants up to $£ 1500$ under the low carbon buildings programme (LCBP), but less than 100 applications a year have been successful. (A total of 360 awards were granted by the Clear Skies Programme and the LCBP between 2003 and 2008 (Bergman and Jardine, 2009;

Micropower Council, 2007).)

Running costs with biomass approach those with natural gas, and are substantially cheaper than oil or electric heating, as shown in Table 3 (Allen et al., 2008b). Small orders of fuel (single bags) are around 50\% more expensive, so having a large store is required to attain low running costs.

3.1.2.2. Emissions. Biomass can be considered a renewable resource if the wood supply is not planted over an existing valuable ecosystem (e.g. peat bogs) and is replaced once harvested. Therefore, carbon savings should only be attributed to biomass on the condition that a new generation is grown to absorb the carbon dioxide released during its combustion. If this is the case, the only life-cycle carbon emissions are associated with harvesting, processing and transporting the biomass. These are estimated to be $15-25 \mathrm{~g} / \mathrm{kWh}_{\text {(fuel) }}$ for wood pellets, compared with $185 \mathrm{~g} / \mathrm{kWh}_{\text {(fuel) }}$ direct emissions from burning natural gas (Defra, 2008b; Elsayed et al., 2003). Using locally sourced biomass would obviously provide the greatest carbon savings by minimising transport requirements.

\subsubsection{Durability and maintenance. Reliability and lifetime} are generally thought to be the same or better than for conventional gas boilers, so long as fuel quality and the boiler itself are properly maintained. Biomass heating requires regular human intervention for fuel delivery and loading, servicing, ash removal, and cleaning. Simple log burners need to be refuelled daily and cleaned once a week, requiring about half an hour's work by the owner (Green Warmth, 2007). The automated fuel

\begin{tabular}{|cc}
\hline Fuel type & Cost: $\mathrm{p} / \mathrm{kW}$ \\
\hline Electricity & $10 \cdot 8$ \\
Oil & $3 \cdot 4$ \\
Natural gas & $3 \cdot 2$ \\
Wood pellets (bulk) & $3 \cdot 0-4 \cdot 2$ \\
Wood logs (bulk) & $1 \cdot 8-2 \cdot 6$
\end{tabular}

Table 3. Retail price of selected heating fuels for residential customers.Wood prices from Defra (2008b); Pellets@LAS (2009); The National Energy Foundation (2008) 


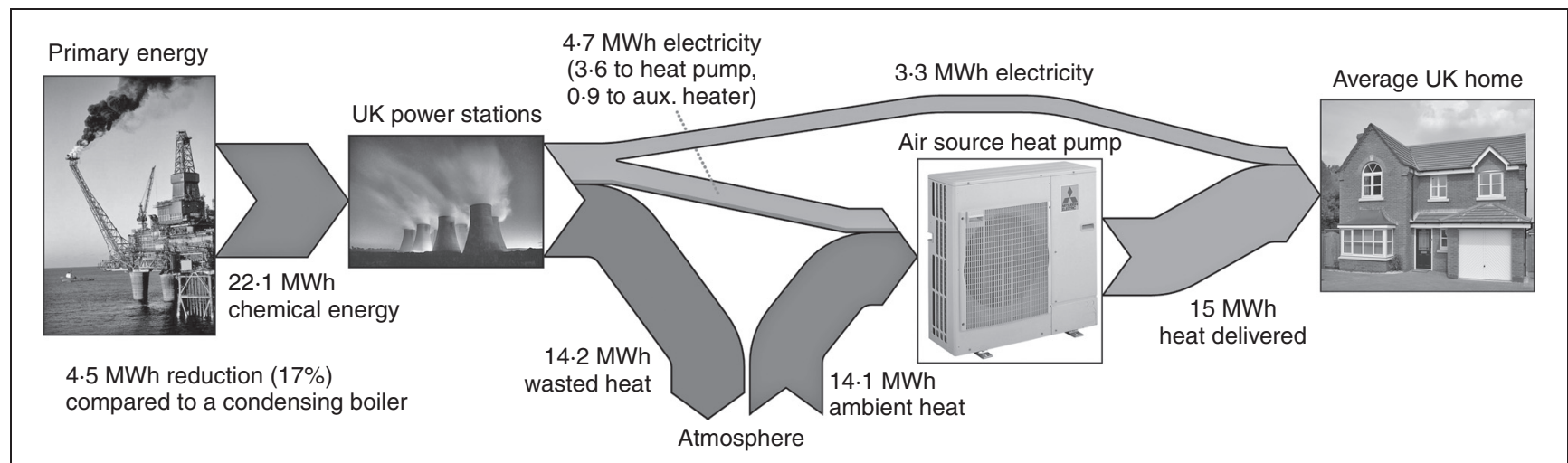

Figure 2. A Sankey diagram showing the flows of energy required to heat and power a typical house for a year using a heat pump. Arrows denote the transfer of energy from one system to another, with thickness that is proportional to the amount of energy. Underlying data based on Miara (2008) and Zeller (2007)

feed and ash collection in more expensive boilers can allow unattended operation for 6-12 months when using pellets, or up to 2 months with logs (SolarFocus GmbH, 2008a).

People who are accustomed to mains gas and electricity perceive refuelling and storage to be a substantial inconvenience with biomass (Element Energy, 2008). While it may not be suitable for all, biomass allows consumers to become more engaged with their energy use, which is key to reducing consumption.

3.1.3. Heat pumps. Heat pumps operate as air-conditioners (or refrigerators) in reverse, extracting ambient heat from the environment and upgrading its temperature for space and water heating. Although they require electricity to operate, the majority of the energy harnessed is 'renewable' heat from the environment, as demonstrated in Figure 2. To heat and power an average UK home with a heat pump, $22 \cdot 1$ MWh of primary energy would be converted to $8.0 \mathrm{MWh}$ of electricity in central power stations, $4 \cdot 7 \mathrm{MWh}$ of which would be used by a typical heat pump to produce $15 \mathrm{MWh}$ of space and water heating. In contrast, the same house using the reference system (an 86\% efficient condensing boiler) would consume $26.6 \mathrm{MWh}$ of primary energy, $17 \cdot 4 \mathrm{MWh}$ of gas for the boiler and $9 \cdot 2 \mathrm{MWh}$ for electricity generation.

Air source heat pumps (ASHP) are similar to widely used commercial air-conditioners, using a small external heat exchanger and circulating fan such as the one pictured in Figure 2. These are easy to retrofit into existing houses, and are viable in urban areas with little surrounding land. ASHP can heat a single room directly (air-to-air), or be connected to the central heating system (air-to-water).

Ground source heat pumps (GSHP) use plastic tubes laid underground as an external heat exchanger. These can be laid horizontally at a depth of $1 \cdot 2-1 \cdot 5 \mathrm{~m}$, which requires extensive digging for trenches (400-800 m of land) (Nu-Heat, 2007). Vertical pipes can instead be laid in two or more boreholes up to $100 \mathrm{~m}$ deep (Canmet Energy Technology Centre, 2002; Viessmann, 2002). Digging boreholes requires planning permission and a geological survey in the UK, but this is an effective option for high-density housing developments as multiple systems can share the same hole.
Heat pumps are usually supplied with a backup heater to pasteurise stored hot water and provide sufficient heating in the depths of winter. Electric immersion heaters are often used for their simplicity and low cost, but their inefficiency increases running costs if used regularly. With careful sizing of the system, use of the immersion heater can be minimised to 3-6\% of the supplied heat in real-world use (Miara, 2008; Zeller, 2007).

Heat pumps have a lower limit on external temperature (around $-15^{\circ} \mathrm{C}$ ), below which the auxiliary heater must be used solely (Viessmann, 2002). ASHPs also need to be defrosted regularly in cold weather as ice builds up on the external heat exchanger. Defrosting increases overall energy use (as heat must be supplied to the outside unit), which can disappoint users who are not made aware of the requirement. (The impact on overall efficiency is not well characterised as it depends strongly on the usage pattern and climate. Importantly, defrosting is excluded from published coefficient of performance (COP) values, so true seasonal efficiency is lower than stated by manufacturers.)

3.1.3.1. Cost. The capital cost of a full heat pump system of either type is in the region of $£ 2500$ to $£ 5000$ (Energy Saving Trust, 2004; MVV Consulting, 2007; Parker (2009, personal communication); Zeller, 2007). Cost per $\mathrm{kW}_{\text {th }}$ decreases sharply with capacity, leading to similar prices for systems in the range 5 to $20 \mathrm{~kW}_{\text {th }}$ (MVV Consulting, 2007). There are however a small number of manufacturers offering basic models in the UK for as little as $£ 1100$ for $5-10 \mathrm{~kW}_{\text {th }}$ capacity (Navitron, 2008; Wharf Heating and Plumbing Supplies, 2008), and smaller air-to-air room heaters are available at up to $4 \mathrm{~kW}_{\text {th }}$ output for around $£ 300$, providing a cost-effective option for smaller dwellings with existing water heating (British AirCon, 2010).

ASHPs are similar to standard heating equipment to install, resulting in estimated total costs in the region of $£ 2000$ to $£ 7000$. The additional labour required to lay the ground pipes for a GSHP increases installation costs by $£ 600-1200$ per $\mathrm{kW}_{\mathrm{th}}$, bringing the total cost up to $£ 10000-12500$ (Energy Saving Trust, 2004; MVV Consulting, 2007; Navitron, 2008). This can be significantly reduced if the GSHP is installed when a new house is built, or if communal holes are used for neighbouring houses. 
Despite high capital cost, heat pumps have passed the breakeven point required to save money in the long run, owing to lower running costs and long operating lifetimes with minimal maintenance (Jakob, 2008). While electricity is 3-4 times more expensive than natural gas, the use of 'Economy 7' or discounted heat pump tariffs can give lower fuel bills than a condensing boiler (Le Feuvre, 2007; The Chartered Institute of Building, 2008). (Economy 7 tariffs in the UK charge approximately half the standard rate for electricity consumed between $1 \mathrm{am}$ and $8 \mathrm{am}$, in exchange for a 10-30\% premium on daytime electricity rates.)

3.1.3.2. Efficiency. The efficiency of the heat pump is the crucial factor in determining the savings it can offer, and is represented by the COP, which is the amount of heat output per unit of electricity consumed. A COP of over 2.5 will provide lower primary energy consumption and carbon dioxide emissions than a condensing boiler in the UK. (With $2.5 \mathrm{~kW}$ of heat output per kW of electricity input, less primary energy would be burnt in UK power stations (average 36\% efficient) than if an $86 \%$ efficient condensing boiler were providing heat.)

The COP of any heat pump is highly dependent on the temperature difference between the external heat exchanger that collects heat and the output to the home and hot water. To maximise efficiency, a warm outside loop and a cool heating loop are desirable, as in practice COP drops by between 0.6 and 1.0 for every $10^{\circ} \mathrm{C}$ difference. As mentioned earlier, large area radiators or under-floor heating improves efficiency, as can heating the air directly with air-to-air room heaters. Newer heat pumps are intended to allow high-temperature operation, enabling compatibility with conventional hydronic heating systems.

During the winter when there is the greatest demand for heating, UK air temperatures average $0-8^{\circ} \mathrm{C}$ (Met Office, 2008). GSHPs benefit from the fact that below $2 \mathrm{~m}$ depth, ground temperature shows little variation during the year, remaining at around $10^{\circ} \mathrm{C}$ (Viessmann, 2002). GSHP therefore offer higher COP values, both nominally and when averaged over the whole year, and they do not have to expend further energy in defrosting the outside unit.

Figure 3 plots the average COP of over 100 commercial models against the temperature rise across the heat pump. The range of performance that could be expected in the UK is highlighted, based on annual climate variations, and the results from eight separate field trials.

3.1.3.3. Durability. Heat pumps exhibit longer lifetimes than conventional boilers, with high reliability and minimal maintenance requirements. Compressors typically have a lifetime of 15-25 years, while heat collectors are expected to last for up to 50 years (Energy Saving Trust, 2000, 2004). These long lifetimes are exemplified by the world's first commercial heat pump, which was installed in 1938 and still provides heat for Zürich city hall (Laue, 2002).

Mean time between failure (MTBF) is reported as being between 20 and 40 years in small-scale GSHPs (Ross, 1990), and only $1 \cdot 7 \%$ of compressors require replacing annually (Canmet Energy Technology Centre, 2002). Coolant leakage from the ground coils is believed to be the most common fault, but this can be avoided by careful installation (Harrogate Borough Council, 2007). As heat pumps present no risks from natural gas explosion or leakage, $£ 50-100$ can be saved annually on gas boiler servicing and inspection.

\subsection{Renewable generation}

Renewables are the most prolific and well-publicised forms of microgeneration. They offer zero-carbon energy with no reliance on fuel purchase, and all of the technologies can recover the embodied energy and emissions from their manufacture within 3 years (Allen et al., 2008a; National Renewable Energy Laboratory, 2004).

High purchase costs are a common feature among the technologies though, in part because uncompetitive markets in the UK allow manufacturers and installers to maintain high profit margins (Bergman and Jardine, 2009). This impacts negatively on the economic viability of these technologies, resulting in financial payback times on the scale of decades (National House Building Confederation Foundation, 2008; Watson et al., 2008). Solar photovoltaics (PV) is for example expected to become cost competitive with retail electricity sometime between 2015 and 2030 (Braun, 2009; Energy Saving Trust, 2005; Lorenz et al., 2008).

The UK receives an average of 1050-1250 kWh/m of solar energy per year (on an optimally inclined plane, annual horizontal irradiance is around $875-1075 \mathrm{kWh} / \mathrm{m}$ ), which is approximately two-thirds of the insolation received in Southern Europe (Jardine and Lane, 2002; Munzinger et al., 2006; Súri et al., 2007). The UK also offers some of the highest average wind speeds in Europe, giving the potential for high energy output in good locations.

Power output from solar technologies varies throughout the day and seasons in a predictable manner, except for the effects of cloud cover. Wind speed varies significantly and unpredictably, meaning turbine output is characterised by rapid fluctuations between zero and full power, with a strong weighting towards low power outputs (Encraft, 2009; Peacock et al., 2008).

While solar energy yield can be estimated with reasonable accuracy, the yield from micro-wind installations depends strongly on the local wind conditions and surrounding geography, which are difficult to quantify. Obstructions such as buildings and trees severely disrupt airflow, slowing it down and creating turbulence which further reduces a turbine's energy yield (Watson et al., 2007). Figure 4 shows a simulation of the wind speeds at roof level around a single building and set of houses. It can be seen that the wind speed is significantly retarded by the profile of the homes, except around specific outlying houses or substantially above roof level.

\subsubsection{Solar photovoltaic. Solar PV are semiconducting} materials that convert energy from sunlight directly into electricity. PV cells are typically made of silicon, but several other materials are available (see Table 4 for a short list). 'Firstgeneration' glass-coated panels are the most common form, however 'second generation' thin films are becoming more widely available, integrated into roof tiles, shingles and foils (Ekins-Daukes, 2009). 

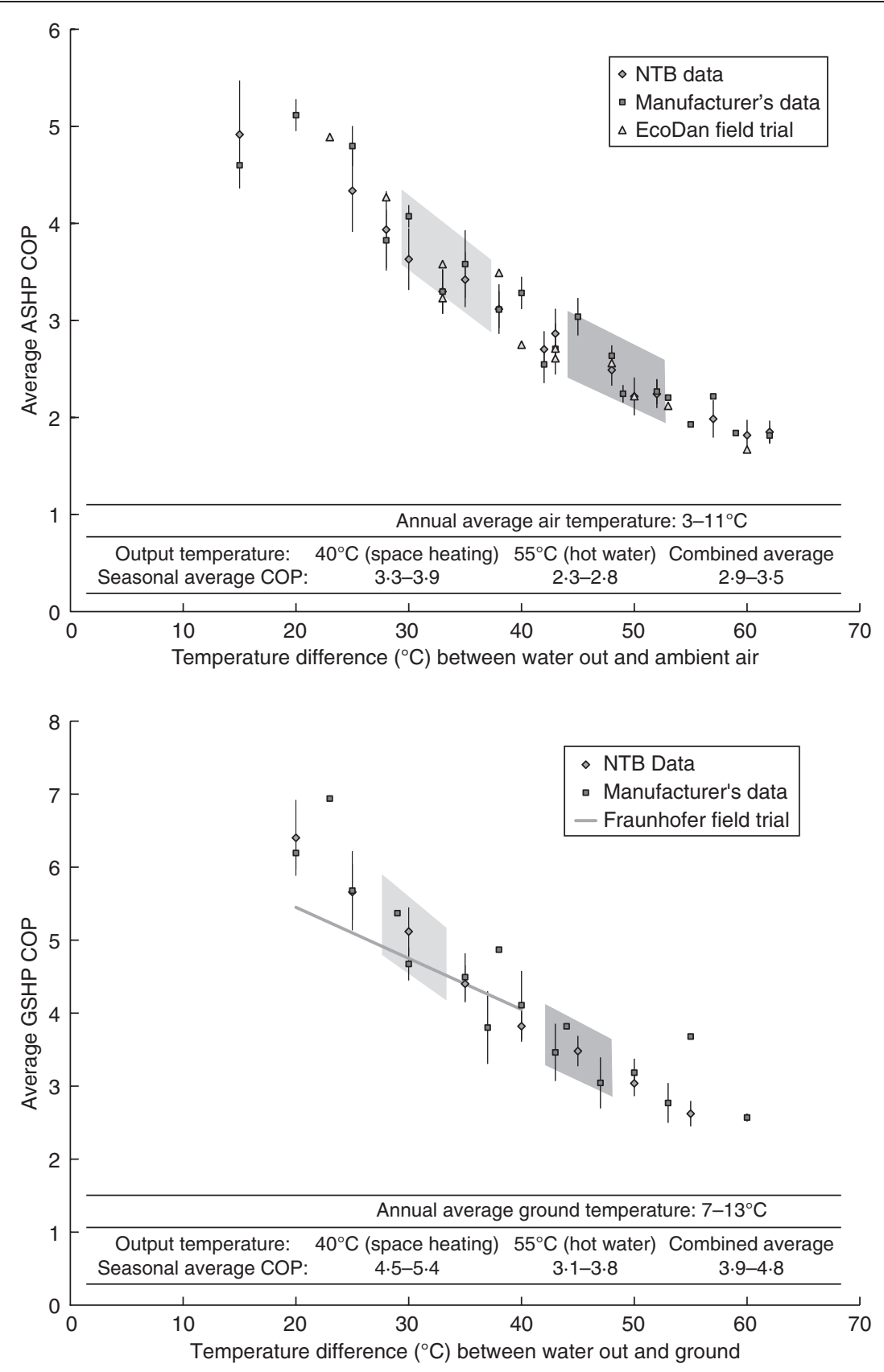

Figure 3. Average coefficient of performance for air and ground source heat pumps. Data taken from industrial surveys and field trials (Miara, 2008; Mitsubishi Electric, 2008; NTB, 2008; Staffell, 2009b)

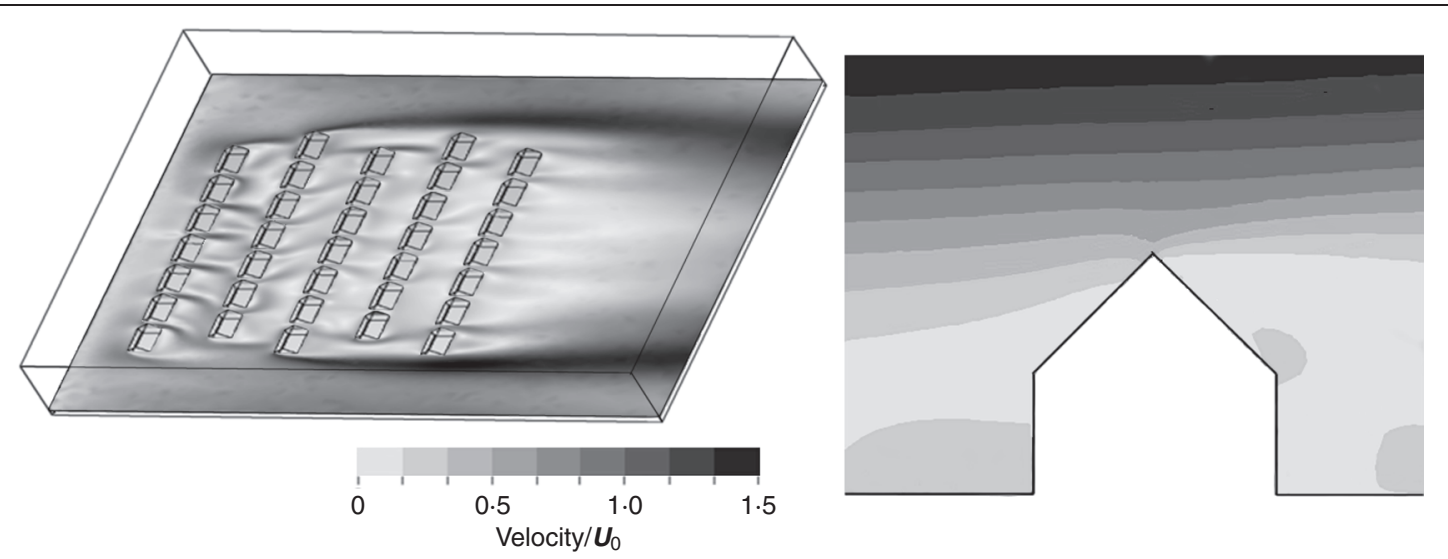

Figure 4. Simulation of the relative wind speeds around houses in an urban area, taken from Watson et al. (2007) 


\begin{tabular}{|c|c|c|c|}
\hline Material & $\begin{array}{l}\text { Typical module } \\
\text { efficiency: } \%\end{array}$ & $\begin{array}{l}\text { Highest recorded } \\
\text { efficiency: \% }\end{array}$ & $\begin{array}{c}\text { Annual UK energy yield: } \\
\mathrm{kWh} / \mathrm{kW}_{\mathrm{pk}}\end{array}$ \\
\hline \multicolumn{4}{|l|}{ First generation: } \\
\hline Mono-crystalline silicon (sc-Si) & 15 & 23 & $710-790$ \\
\hline Multi-crystalline silicon ( $\mathrm{p}-\mathrm{Si} / \mathrm{mc}-\mathrm{Si})$ & $8-12$ & $15 \cdot 5$ & $690-800$ \\
\hline Heterojunction with intrinsic thin layer (HIT) & $16-23$ & - & $\sim 750$ \\
\hline \multicolumn{4}{|l|}{ Second generation: } \\
\hline Amorphous silicon (a-Si/a-SiGe) & 4-6 & $10 \cdot 5$ & $620-900$ \\
\hline Cadmium telluride (CdTe) & 7 & 11 & $560-760$ \\
\hline Copper indium/gallium (Di)selenide (CIS/CIGS) & 9 & $13 \cdot 5$ & $820-1000$ \\
\hline \multicolumn{4}{|c|}{$\begin{array}{l}\text { Table 4. A comparison of the laboratory efficiencies and demonstrated energy yields for different designs of solar PV module. Module } \\
\text { efficiencies are for non-concentrating cells ( } 1000 \mathrm{~W} / \mathrm{m} \text { irradiation) taken from Green et al. (2009), Jardine and Lane (2003) and } \\
\text { SANYO (2009). Annual alternating current (AC) yields were measured from several panels mounted on university rooftops, taken } \\
\text { from Jardine and Lane (2002), Williams et al. (2005) and Zinßer et al. (2007). Note that the annual yields measured by Zinßer et al. } \\
\text { were scaled linearly to account for the irradiation received in Stuttgart relative to Oxford }\end{array}$} \\
\hline
\end{tabular}

The direct current (DC) output of individual modules is connected in series to form an array, which is connected to an inverter that determines the optimum combination of voltage and current draw to maximise the power output. A typical domestic installation of $2 \mathrm{~kW}_{\mathrm{e}}$ peak output $\left(\mathrm{kW}_{\mathrm{e}, \mathrm{pk}}\right)$ can consist of 10-20 modules of around $1-1.5 \mathrm{~m}^{2}$ each.

3.2.1.1. Cost. Prices fell sharply during 2009 as the global recession eased demand for silicon. As of December 2009, solar module prices were on average $£ 2600-3800$ per $\mathrm{kW}_{\mathrm{e}, \mathrm{pk}}$, although the cheapest silicon modules cost just £1200 per $\mathrm{kW}_{\mathrm{e}, \mathrm{pk}}$ (Solarbuzz, 2009). The average cost of modules installed in UK field trials was similar, at Ł3430 per kW $\mathrm{e}_{\mathrm{e} p \mathrm{pk}}$; however, building integrated panels were nearly twice as expensive at $£ 6380$ per $\mathrm{kW}_{\mathrm{e}, \mathrm{pk}}$ (Munzinger et al., 2006).

Complete systems are more expensive as they include the cost of an inverter (around $£ 500$ per $\mathrm{kW}_{\mathrm{e}}$ ) (Munzinger et al., 2006), and other system components, plus installation costs which vary significantly between sites. The total cost of retrofitting $2 \mathrm{~kW}_{\mathrm{e}, \mathrm{pk}}$ panels onto existing roofs was therefore $£ 10000$ 13000 , reducing to £800011000 for new-build installations (Bergman and Jardine, 2009; Munzinger et al., 2006).

\subsubsection{Efficiency and energy} output. The efficiency of PV cells depends on the materials used, and as seen in Table 4 crystalline silicon still offers higher efficiencies than second-generation thin-film cells. This is not a particularly useful measure of PV performance though, as it is measured under standard laboratory conditions which are not matched in reality. The only practical benefit of higher efficiency panels is to require less roof space, which is not usually a constraint.

Real-world performance is measured in terms of the annual energy yield expressed per $\mathrm{kW}_{\mathrm{e}, \mathrm{pk}}$ of panel, which depends on the level of insolation received, the spectral quality of the light and panel temperature (Jardine and Lane, 2002). Table 4 also gives the annual AC yields measured from different types of panel in the UK and northern Europe, which shows little correlation to the laboratory efficiencies. Thin film CIS/CIGS and amorphous silicon cells appear to be the most effective technology in the UK despite having a relatively low efficiency, owing to their better performance in cold climates and overcast conditions (Gottschalg et al., 2003; Jardine and Lane, 2003).

Extensive field trials of PV systems in the UK have demonstrated somewhat lower annual yields of $705 \pm 107 \mathrm{kWh} /$ $\mathrm{kW}_{\mathrm{e}, \mathrm{pk}}$ over 3 years, as shown in Figure 5. The average yield on domestic rooftops was somewhat lower than measured in

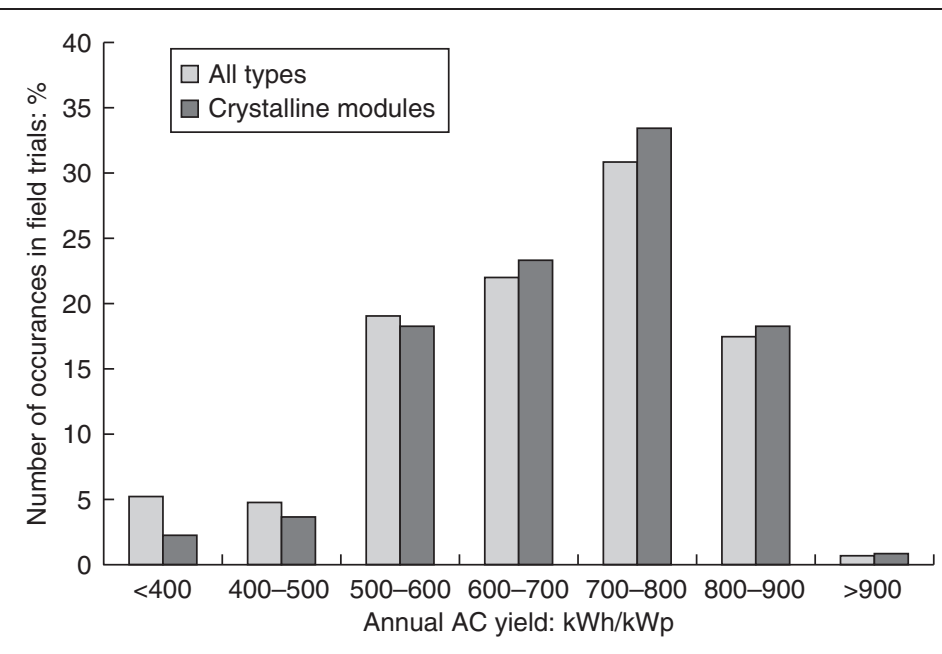

Figure 5. Histogram showing the annual yields from 44 I system-years of PV operation, with a separate assessment of crystalline silicon modules. Roof integrated tiles and laminate systems performed slightly worse owing to higher cell temperatures and greater impact of panel shading (Munzinger et al., 2006) 


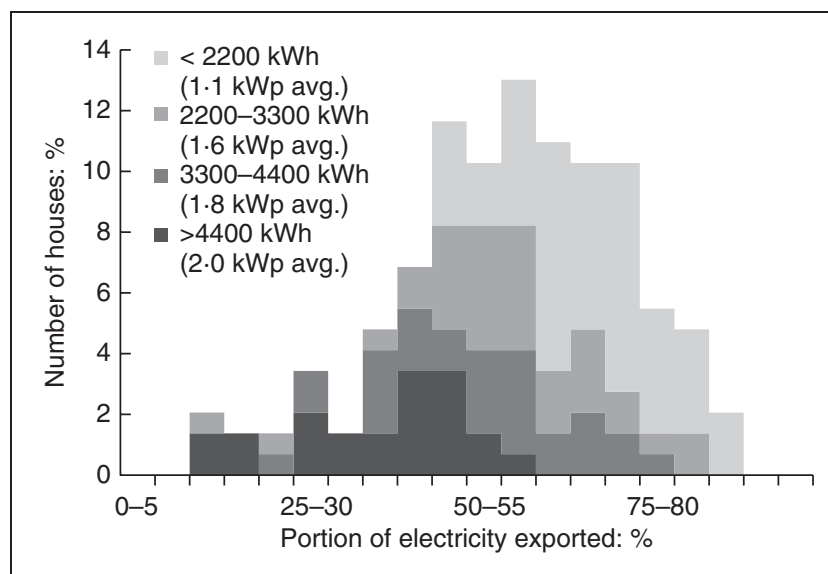

Figure 6. Histogram showing the fraction of exported electricity from solar PV panels installed in 229 houses. The houses are categorised by their annual electricity demand (in kWh per year), and the average size of installed panels is given in parentheses. Underlying data from Department of Trade and Industry (DTI, 2007)

academic studies, as over two-thirds of systems suffered from reduced power output because of shade covering the panels and inverter downtime (Munzinger et al., 2006). The impact of building extensions such as satellite dishes and the growth of neighbouring trees must be carefully considered to avoid obstructing the panels by shade. Similarly, the uptime of inverters must be monitored carefully, as voltage spikes and grid instability can cause frequent shutdowns. Ensuring that the inverter is restarted quickly is essential to minimising the impact of these events, but requires better systems design and education for the owners.

Of the electricity produced by these $1-2 \mathrm{~kW}_{\mathrm{e}, \mathrm{pk}}$ panels an average of $56 \pm 16 \%$ was exported to the national grid (Munzinger et al., 2006), which lies within general expectations (Ilex Energy Consulting, 2005). As shown in Figure 6, the proportion of export has an obvious relation to the electrical demand of the property.

3.2.1.3. Durability. The durability and reliability of PV are extremely good, as no moving parts or organic materials are used. It is typical for PV modules to have a guaranteed lifetime of at least 25 years, and advanced ageing techniques suggest that modules could last more than 50 years before falling below their guaranteed output voltage (Wohlgemuth et al., 2005). Even with zero maintenance, the long-term rate of power loss is very low, with $0 \cdot 6$ and $0 \cdot 3 \%$ decrease per year seen over 27 and 14 years respectively (King, 2004; Tang et al., 2006).

It is impossible to prove such long lifetimes at present, as the majority of the world's installations are less than 20 years old. (The oldest functioning PV system is thought to have been assembled in 1965, and was last checked in 2000 (Bridges, 2000). The oldest monitored terrestrial systems were replaced after 27 years of service (beginning in 1976), after which twothirds of the panels were still functional, producing $71 \%$ of their original power (Tang et al., 2006).) At present, the inverter is the most fragile component of the entire system, and will typically require replacing after 10-15 years (Fronius, 2009; Navigant Consulting, 2006).

3.2.2. Solar thermal. The basic concept of solar water heating has been employed for many decades, even pre-dating the widespread use of electricity or gas for heating (Perlin, 2005). Owing to the predominantly overcast conditions during the UK winter, solar thermal provides a poor match with space heating requirement. Arguably, it could prove worthwhile in Scotland where the heating season extends into summer, as has been demonstrated in mountainous and desert regions with good solar resource and cool ambient temperatures (Argiriou et al., 1997; Practical Action, 2006).

Heat from the sun is absorbed by the black surface of a solar collector. A working fluid (often water plus antifreeze) is pumped to the surface of this collector, transferring heat to the house through an exchange coil at the bottom of a water storage tank.

There are two main types of solar collector: flat plate and evacuated tube. In a flat plate system, solar heat is absorbed by a flat metallic surface with a selective black coating, to allow good absorption and low re-radiation of the heat. Heat is collected by a fluid flowing through pockets in the plate, or pipes in contact with the plate. This is encased in an insulated box structure with a transparent face that is usually double glazed.

Evacuated tube systems vary in their design, but all contain several partially evacuated glass tubes with a selectively coated heat absorber. They offer higher efficiency than flat plate collectors, and can deliver higher temperature water as heat losses in the collector are reduced. However, they are more complex and energy intensive to manufacture, making them the more expensive design.

The only energy input required for operation is for the control system and pump that circulates the working fluid. Certain systems incorporate a PV panel to drive the pump and thus only operate when there is sufficient sunlight; however, this can reduce system performance if there is no system controller to optimise pump operation.

3.2.2.1. Cost. Solar thermal technology ranges from simple DIY systems costing just a few hundred pounds up to sophisticated and professionally installed systems costing thousands. The more advanced products can supply a greater portion of water heating needs, giving a faster return on the energy and carbon invested in their construction. These are therefore the systems that are eligible for government grants; however, it is the cheaper systems that prove to be more cost effective (Bergman et al., 2009). Economic assessments tend to consider only the most expensive and sophisticated systems and current installation costs, leading to unacceptably high payback times.

Expensive components or manufacturing techniques are not required, hence basic flat plate systems can be sold for as little as \$200 in China (Graham-Harrison, 2006). Bare systems in the UK retail for around $£ 1500$ (Solar4U Ltd, 2009), but fully installed costs range from $£ 2000$ up to $£ 8000$ (Bergman and Jardine, 2009; Ekins-Daukes, 2009). The additional expense 
covers installation of the panel, often with a new heat storage tank and a new condensing boiler. There is little technical justification for the observed price differential except that installation is much simpler in new-build houses, resulting in half the average cost of retrofitting (Ekins-Daukes, 2009; Fisher et al., 2008).

\subsubsection{Energy output. Domestic installations typically use} between 2 and $4 \mathrm{~m}^{2}$ of panel or tubes, which can absorb up to $70 \%$ of the incident radiation, of which $60-70 \%$ can be transferred to the water tank in a well-run system (Martin and Watson, 2001). Based on field trial results, a $4 \mathrm{~m}^{2}$ system is capable of delivering around 1400-1700 kWh of hot water per annum, while only drawing 30-90 kWh of electricity to power the pump (Forward et al., 2008; Martin and Watson, 2001; Streicher et al., 2004).

Energy yields from solar thermal installations are modest in one- and two-person households owing to relatively low demand for hot water. Yields can be significantly greater in family homes, but the majority of installed panels achieve only a quarter of their potential owing to a complex web of behavioural reasons (Hill, 2009).

As mentioned previously, setting the auxiliary heating system to run before the panel has preheated water can drastically reduce the output (Forward et al., 2008), while an oversized panel will conversely produce excess hot water that is not needed during summer (The Energy Monitoring Company Ltd, 2001). A suitably sized system when operated correctly should be able to provide $50-70 \%$ of household hot water demand (The Energy Monitoring Company Ltd, 2001). However, the typical manufacturers' claim of providing up to 70\% of hot water demand is not widely experienced in the field (Forward et al., 2008; Hill, 2009).

3.2.2.3. Durability. Very little has been published on the durability of solar thermal panels, but it is expected that systems should last 30 years or more with minimal maintenance (Croxford and Scott, 2006; Fisher et al., 2008). Maintenance is relatively simple, topping up antifreeze and water levels every few years.

3.2.3. Micro-wind. The UK has a world-leading manufacturing industry for small wind systems, and the domestic market has grown solidly in recent years (BWEA, 2008b). However, a spate of bad publicity surrounding poor performing urban installations has damaged public confidence in the technology (Brinkley, 2006; Jowit, 2009; Vaughan, 2009).

The design of micro-wind turbines are more varied than the iconic 3-bladed MW-scale turbines, including 2-6 bladed horizontal, vertical, and cross-flow designs, plus buildingaugmented turbines (Allen et al., 2008b; European Commission and Intelligent Energy, 2007). Micro-turbines are designed to minimise noise and vibration, and must be able to operate in more turbulent conditions, with rapid changes in wind speed and direction.

Horizontal axis wind turbines (HAWT) are the most common and well-developed design, offering the greatest performance at present. Domestic models have 1·7-2 m blade diameter, and are typically mounted on buildings at 2-3 $\mathrm{m}$ above the roof-line, giving a maximum height of 3-4 m (BWEA, 2008b).

Under proposed government reforms such installations would not require planning permission in the UK, removing a major obstacle for customers at present (BWEA, 2008a). However, delays in enacting this legislation have been blamed by the micro-wind industry for stifling uptake and commercial viability (Northrop, 2009).

\subsubsection{Cost. Installed costs start from $£ 1900$ for the most} popular UK model - the $1 \cdot 2 \mathrm{~kW}_{\mathrm{e}}$ Windsave. (The Windsave was prominently sold in a national chain of hardware stores until February 2009, and the manufacturer has since been liquidated.) The $0.6 \mathrm{~kW}_{\mathrm{e}}$ Ampair turbine costs $£ 1575$ plus $£ 1500-2500$ for the mounting, installation and inverter (Ampair Microwind, 2009; Windsave, 2009). Mast-based turbines above $5 \mathrm{~kW}$ (suitable for rural locations) are significantly more expensive, and incur additional costs with electrical interconnection. Planning permission adds an extra $£ 200$ to the installation costs in the UK; however, government grants of 30\% of the total cost are available through the LCBP (BERR, 2009a).

\subsubsection{Energy output. Despite the range of designs, most} wind turbines exhibit similar power curves with varying wind speed, like the ones shown in Figure 7. At very low wind speeds, the turbine torque is insufficient to overcome friction and power conversion losses, so no net power is produced. Between the

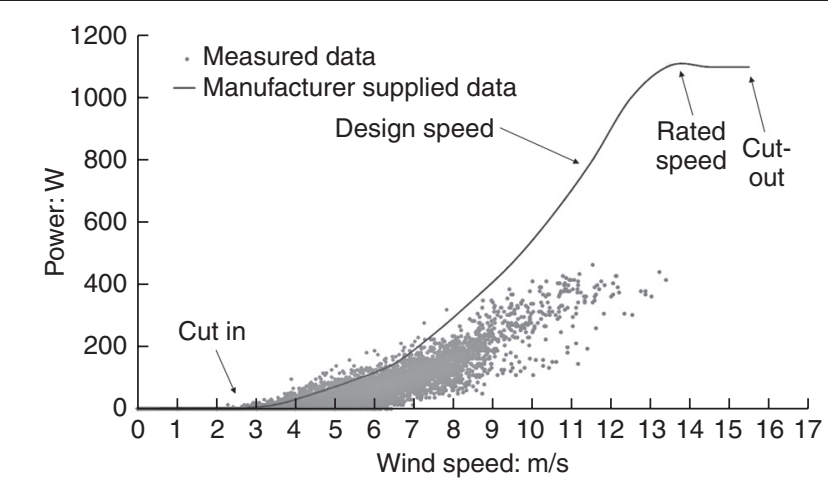

(a)

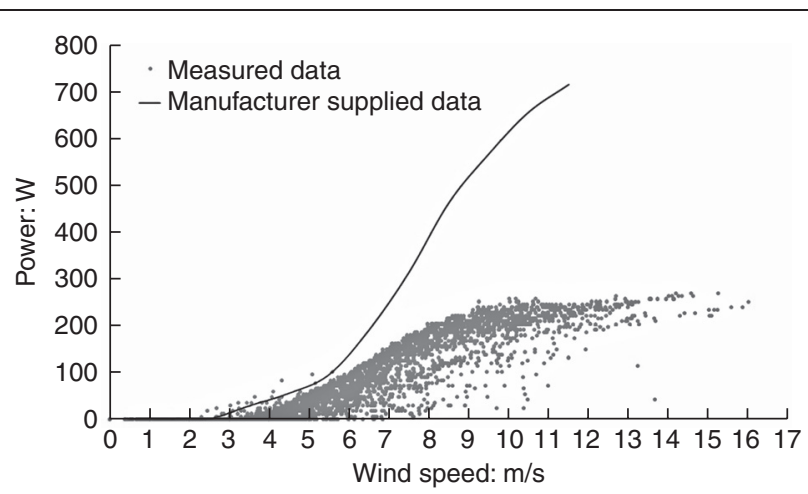

(b) 
cut-in and design wind speeds (typically 3 to $10 \mathrm{~ms}^{-1}$ ), the turbine power approximately increases with the cube of wind speed, operating close to optimum efficiency. As the wind speed approaches rated design speed (e.g. $12 \mathrm{~ms}^{-1}$ or gale force 6), the power output levels off as the generator and gearbox are at maximum capacity. In some models, the turbine shuts down at higher wind speeds to protect itself from damage.

There is no simple method of estimating the energy yield at a particular site, so wind speeds should ideally be measured for up to a year at the actual position the turbine would be installed. Time and cost prevents this from being commonplace, and so installers perform a basic site survey using the NOABL database of high-altitude wind speeds (BWEA, 2009b), applying simple correction factors for rural, urban and high-rise areas to account for surface disturbances. This method has been shown to systematically overestimate the wind speeds experienced at actual installation sites, and thus predict energy yields that were around double those actually achieved (BWEA, 2009a; Encraft, 2009). This has led to widespread calls for an improved estimation method, examples of which have been developed recently (Encraft, 2009; Phillips et al., 2007). Much of the negative opinion about micro-wind has been the result of unmet expectations caused by oversimplified estimates about achievable yield.

These effects have been demonstrated in two separate UK field trials, where the average net energy yield was just $53 \mathrm{kWh}$ per year, a capacity factor (defined as the actual output divided by the maximum possible output (e.g. $1 \cdot 2 \mathrm{~kW}_{\mathrm{e}}$ produced for $8760 \mathrm{~h}$ per year); a $10 \%$ capacity factor is therefore equal to $876 \mathrm{kWh} /$ $\mathrm{kW}_{\mathrm{e}, \mathrm{pk}}$ of $0 \cdot 85 \%$ ), and no urban or suburban building mounted sites generated more than $200 \mathrm{kWh}$ (Encraft, 2009; Energy Saving Trust, 2009). It was known that many of the turbines were installed in poor locations with low wind speeds (BWEA, 2009a; Encraft, 2007), but as seen in Figure 7 the measured power output was lower than manufacturers' power curves at all wind speeds, even in suitable locations. In addition, power converters consumed an average of $29 \mathrm{kWh}_{\mathrm{e}}$ per year making some turbines a net consumer of electricity (Energy Saving Trust, 2009), and significant downtime was experienced owing to turbine failure and complaints about noise (Encraft, 2009).

Separate simulations of localised wind speed suggest that capacity factors of only a few per cent should be expected from urban areas (Clark et al., 2008; Phillips et al., 2007). Suburban capacity is generally higher but will remain under $10 \%$, while 15-20\% could be achieved in ideal rural locations (Clark et al., 2008). These figures are confirmed by the performance of freestanding rural turbines, which averaged 16.5\% and 19\% capacity factors in the two UK field trials (Encraft, 2009; Energy Saving Trust, 2009), and by larger $\left(5-10 \mathrm{~kW}_{\mathrm{e}}\right)$ turbines installed on isolated masts or multi-storey tower blocks, which achieve 8-12\% (Brian Dunlop Associates, 2008; Encraft, 2009).

It is therefore widely advised that turbines are not installed in urban areas, with the simple guidance being 'the more rural the location, the better resource there is for wind generation' (Clark et al., 2008). Some isolated urban and suburban houses can offer the minimum average wind speeds of $5 \mathrm{~ms}^{-1}$ required for recommended locations (Energy Saving Trust, 2009), but these could only be identified with detailed modelling shown earlier in Figure 4, or with prior measurements.
3.2.3.3. Durability. There is little long-term experience with building mounted micro-turbines owing to their relative immaturity, and so lifetimes are only estimated rather than evidence based. Manufacturers and organisations expect lifetimes to be in the region of 15 to 22.5 years (Allen et al., 2008a; Ampair Microwind, 2008; BERR, 2009c). However, there have been problems with the reliability of early models; for example, the Warwick Microwind Trial resulted in a number of catastrophic failures, with blades and tail fins being ripped from the turbine (Encraft, 2009).

\subsection{Micro-CHP}

The primary benefit of combined heat and power (CHP) operation is the reduction in primary energy use and fuel costs that can be gained by converting natural gas into both heat and electricity at the point of use. Capturing and using the byproduct heat from generation allows for greater total efficiency than top performing combined cycle gas turbine (CCGT) power plants. These benefits are illustrated in Figure 8, which shows the primary energy consumed in supplying the energy needs of a house with a fuel cell micro-CHP system. Note that the energy flows will vary significantly depending on the type of CHP technology owing to their different efficiencies.

Natural gas is the most widely used fuel in domestic CHP systems, owing to its low cost and widespread infrastructure in the UK. However, both engine and fuel cell technologies have been demonstrated running on fuels derived from biomass (Onovwiona and Ugursal, 2006; Thomas, 2008). This point is crucial for the long-term suitability of these technologies, as the window of opportunity for fossil-fuelled CHP is speculated to be 20-30 years (Harrison, 2008b). Development of these technologies, while criticised by some as a distraction from truly sustainable energy, can thus be seen as a stepping stone towards the ideal renewable CHP system fired on biomass.

The total efficiency offered by all micro-CHP technologies depends upon the level of integration with the heating system and whether condensing heat exchangers are employed. Total efficiencies for all generating technologies are therefore similar, being in the region of 75-85\% HHV. Typical electrical efficiencies differ by a factor of 10, meaning these technologies offer substantially different levels of improvement over heatonly boilers.

Electrical efficiencies are profoundly influenced by the operating pattern of the CHP device over the course of time, which makes real-world performance diverge from that of controlled laboratory tests (Kuhn et al., 2008). Operation is usually intermittent and infrequent in summer when there is little demand for heat, meaning that devices are repeatedly cycled on and off. Energy is required during start-up to power pumps and controllers, and to heat the core generator to operating temperature, meaning intermittent operation adds significantly to natural gas and electricity consumption (Carbon Trust, 2007; Staffell, 2009a). The heat contained in the generator is dissipated to the surrounding area of the house, which may be useful during the heating season but is effectively wasted in summer (Kuhn et al., 2008). The annual efficiencies reported in field trials are therefore lower than reported by manufacturers' specifications and steady-state measurements. 


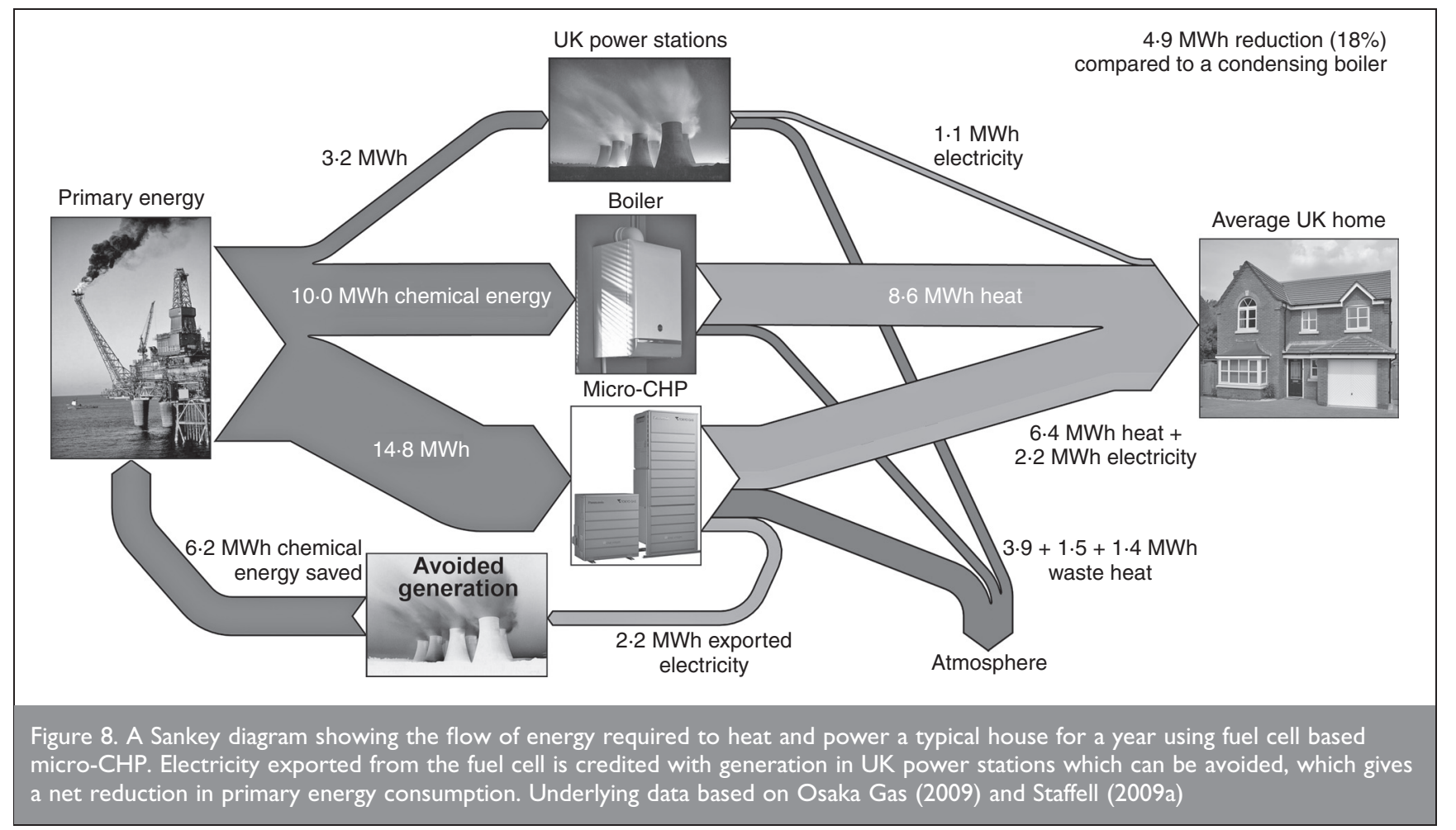

3.3.1. Internal combustion engines. Reciprocating internal combustion engines (or IC engines) are similar to the wellestablished automobile engine, and thus are a reliable and well-proven technology. They are commonly used in commercial and industrial CHP systems with electrical capacities of $10-100 \mathrm{~kW}_{\mathrm{e}}$, but smaller versions are available for domestic micro-CHP. These are based on spark ignition (0tto) engines, running on natural gas (Onovwiona and Ugursal, 2006).

There is little variation between the mechanisms of different IC engines: natural gas is ignited by a spark plug, which forces a piston to drive a crankshaft mechanism connected to a gridsynchronised AC generator. Heat is extracted from the engine at around $150^{\circ} \mathrm{C}$ through exhaust gasses and cooling fluid that is pumped around the chambers (Onovwiona and Ugursal, 2006).

Engine designs have an optimal running speed that gives minimum fuel consumption. Reducing power output requires the engine speed to fall, consequently lowering efficiency. Domestic scale systems use an asynchronous AC generator which requires the engine to run at a fixed speed, and so load modulation is not possible. Instead, micro-CHP engines cycle on and off according to the amount of hot water demanded (Aki, 2007). A learning algorithm is employed based on the past patterns for hot water demand, enabling the system to maximise its operating hours (Aki, 2007; Kayahara, 2002).

One drawback of engines has been high operating noise levels, making them unsuitable for frequently used areas of a dwelling. By housing the engine in a sound-proofed enclosure, the noise levels are reduced to those of a standard refrigerator $(\sim 45 \mathrm{~dB})$ (Kayahara, 2002). Complete systems are generally larger and heavier than a condensing boiler $(\sim 85 \mathrm{~kg})$, and thus need to be floor-standing units (Honda Motor Co., 2007).
3.3.1.1. Cost. A handful of companies produce mini-CHP engines, which are significantly larger than domestic units, weighing over half a tonne and producing $5 \mathrm{~kW}_{\mathrm{e}}$ of 3-phase power. Chief among these are the Dachs designed by Senertec and marketed by Baxi, the Vaillant EcoPower, and the family of engines from Yanmar. The only engine suitable for singlefamily domestic properties is the $1 \mathrm{~kW}_{\mathrm{e}}$ Honda ECOWILL (introduced to the American market under the brand name of Freewatt, planned for introduction to Europe early next decade), which produces $2 \cdot 8 \mathrm{~kW}_{\text {th }}$ of heat directly, and a further $36 \mathrm{~kW}_{\mathrm{th}}$ from a supplementary boiler (Aki, 2007; Honda Motor Co., 2007).

The prices for some of the above models are given in Table 5 . A strong dependence on capacity is seen, with the

\begin{tabular}{|c|c|c|}
\hline Model & Cost & Reference \\
\hline ECOWILL & $\begin{array}{l}\text { On sale for } £ 3750-4000 \text {, } \\
\text { with } £ 750 \text { subsidies } \\
\text { available from the } \\
\text { Japanese government }\end{array}$ & $\begin{array}{l}\text { (Hokkaido Gas Co., } \\
\text { 2009; Osaka Gas Co., } \\
\text { 2009; Tokyo Gas Co., } \\
\text { 2008) }\end{array}$ \\
\hline Freewatt & $\begin{array}{l}\text { Approximately } £ 7000 \text {, } \\
\text { fully installed with a } \\
\text { warm-air heating system }\end{array}$ & (Treehugger, 2007a) \\
\hline Dachs & $\begin{array}{l}£ 10000-14000 \text { fully } \\
\text { installed }- \text { equating to } \\
£ 2000-2800 / \mathrm{kW}\end{array}$ & $\begin{array}{l}\text { (Senertec, 2002; } \\
\text { Treehugger, 2007b) }\end{array}$ \\
\hline EcoPower & $\begin{array}{l}\text { Marketed by Vaillant for } \\
\text { approximately } £ I I 000 \text {, } \\
\text { equating to } £ 2400 / \mathrm{kW}\end{array}$ & $\begin{array}{l}\text { (Vezzini, 2004; Wilcox } \\
\text { 2004) }\end{array}$ \\
\hline
\end{tabular}

Table 5. Costs for commercially available IC engines 
ECOWILL/Freewatt engine costing two to three times as much per $\mathrm{kW}_{\mathrm{e}}$ than the larger Dachs or EcoPower. Installation costs appear to be in the region of $£ 2000-3000$, which is approximately 50\% more than the cost of installing a condensing boiler.

Running costs are often cited as an issue for engines, yet in modern systems they are similar to those for conventional technologies. Senertec estimates that maintenance of the Dachs costs $£ 30-40$ per year (Senertec, 2002), which falls within the range $£ 4-10$ per $\mathrm{MWh}_{\mathrm{e}}$ estimated by academic authors (Onovwiona and Ugursal, 2006). Free maintenance contracts of up to 10 years are offered in Japan to promote ECOWILL sales (Tokyo Gas Co., 2008).

\subsubsection{Efficiency. Manufacturers of larger engines quote} efficiencies in the region of 25-30\% electrical and 85-90\% total HHV, when using condensing heat exchangers (Osaka Gas Corporation, 2002; Senertec, 2008; Senertec, 2009; Yanmar, 2009). When these values were tested independently, the Dachs and EcoPower were measured to have only $82 \%$ and $79 \%$ total efficiency respectively (Thomas, 2008).

Real-world performance has been confirmed in three separate field trials of larger mini-CHP units, where 21-25\% electrical and up to $84 \%$ total efficiency were reported (Carbon Trust, 2007; Onovwiona and Ugursal, 2006; Teekaram, 2005). These engines were run constantly to meet the base load demands of the building, and thus did not demonstrate reduced performance from cycling.

Results from demonstrations of the ECOWILL have not been published, so real-world performance can only be assumed from the quoted specifications of 20.5\% electrical, 77.5\% total (Aki, 2007). This reflects the fact that the electrical efficiency of engines is expected to fall with capacity (Onovwiona and Ugursal, 2006).

3.3.1.3. Emissions. Emissions from IC engines are typically the highest of any micro-CHP technology owing to the combustion conditions within the engine. Emissions of nitrogen oxides and carbon monoxide from the Dachs are around double those of a gas boiler, with $270 \mathrm{mg}$ nitrogen oxide and $50 \mathrm{mg}$ carbon monoxide produced per kWh of fuel burnt (Teekaram, 2005). The EcoPower engine uses a three-way catalytic converter to reduce emissions to approximately zero carbon monoxide and $80 \mathrm{mg}$ nitrogen oxide per kWh of fuel (Rock Energy, 2007; Thomas, 2008). The Honda ECOWILL could be expected to have a similarly low emissions profile, as it also employs a catalytic converter with oxygen control (Honda Motor Co., 2004).

\subsubsection{Durability and maintenance. Engine durability is} generally good, with lifetimes of 80000 operating hours or 20 years advertised for the Dachs (Baxi-SenerTec UK, 2006; Senertec, 2009). Opinion is divided on whether this could be achieved with domestic-scale engines as the initial specification for the ECOWILL in 2002 was for only $20000 \mathrm{~h}$ (Pehnt et al., 2006; Praetorius and Schneider, 2006), although as this engine runs intermittently throughout the year this is expected to give a 10-year lifetime (Kayahara, 2002).

The moving parts of the engine have been cause for concern owing to the imposed maintenance requirements which are similar to a vehicle engine: frequent changes of oil, coolant and spark plugs. The problems are overstated, as scheduled maintenance for the ECOWILL is only required every $6000 \mathrm{~h}$ (3 years) (Kayahara, 2002). Maintenance can however involve major overhauls of the engine and heat exchanger, meaning that over the whole lifetime, the cost of servicing can add up to the initial purchase (Pehnt et al., 2006).

\subsubsection{Stirling engines Stirling engines differ from IC engines} in that fuel combustion occurs outside of the cylinders, which are completely sealed and filled with a light pressurised gas. Combustion is continuous and more tightly controlled than with explosive internal combustion, removing the need for catalytic converters and reducing engine noise levels (Onovwiona and Ugursal, 2006).

There are several possible configurations for the engine and the mechanism for generating electricity. Systems with kinematic drive use a mechanical connection to the generator as with an IC engine, while modern free-piston designs extract electricity more efficiently with a linear alternator that exploits the pressure differentials in the gas chamber (Onovwiona and Ugursal, 2006). Heat extraction is the same as for IC engines in all designs.

Stirling engines produce significantly more heat than electricity, and so are operated to follow the heat demands of the house, and can only run intermittently during summer.

\subsubsection{Cost. As with IC engines, there are several mini-CHP} engines available above $5 \mathrm{~kW}_{\mathrm{e}}$, but only one product at present which is suitable for the domestic market: the WhisperGen (Whisper Tech, 2004, 2008b). This is based on the kinematic piston design, and has an output of up to $1 \mathrm{~kW}_{\mathrm{e}}$ plus $8-13 \mathrm{~kW}_{\text {th }}$.

Newer engines based on the free-piston design are under development by both Baxi and Enatec (Baxi Innotech, 2007; Enatec Micro-cogen B.V., 2007). The Baxi Ecogen offers a lower heat-to-power ratio of 5:1 and is packaged into a compact wall-hung unit with an auxiliary condensing boiler (Baxi, 2008). Both the WhisperGen and Ecogen were expected to go on sale during 2009, however at the time of writing neither product has moved beyond extended field trials and been commercially launched in the UK (Baxi, 2009; E.ON UK, 2009).

Stirling engines are expected to cost more than IC engines owing to the precision engineering required; however, at present the WhisperGen is the cheapest micro-CHP system available. This appears to be attributable to heavy subsidies provided in the UK, where limited numbers have been made available for $£ 3000$, compared with $£ 11000$ in Germany (Green Consumer Guide, 2005; Harrison, 2008q). Maintenance costs are expected to be lower than for IC engines owing to the reduced mechanical wear (Onovwiona and Ugursal, 2006).

\subsubsection{Efficiency. The electrical efficiencies reported for} Stirling engines vary widely between sources, and can be as high as 15-30\% (Energie-Cités, 2000; Whisper Tech, 2003). Efficiency falls sharply as unit capacity decreases though, and so smaller micro-CHP systems have efficiencies of only $4-6 \%$ 
for kinematic designs (e.g. WhisperGen), or up to $12 \%$ for free-piston designs (e.g. Ecogen) (Baxi, 2008; Gummert, 2008; Whisper Tech, 2008a).

WhisperGen efficiencies have been verified in large-scale field trials conducted by the Carbon Trust in the UK. After a year of operation, 74 units demonstrated 4-8\% electrical and 75-80\% overall efficiency (Carbon Trust, 2007). Smaller studies of realworld performance have also reported electrical efficiencies of $5 \cdot 5-9 \%, 5 \cdot 5-8 \%$ and $6 \cdot 5-11 \%$ from different models, with total efficiencies of 80-88\% (Entchev et al., 2004; Veitch and Mahkamov, 2009; Woude et al., 2004). Worryingly, the Carbon Trust found that for an average of 30-40 days per year, electrical efficiencies were between 0 and $2 \%$, and were sometimes not enough to cover the $100 \mathrm{~W}_{\mathrm{e}}$ required to run the engine's pumps and control unit (Carbon Trust, 2007).

Operating patterns have the most notable impact on Stirling engines, as their large heat output significantly limits operation in summer. Electrical as well as total efficiencies are strongly affected by length of operating periods - falling from $5-7 \cdot 5 \%$ in winter months to just $2-5 \cdot 5 \%$ during summer. Around $0.5 \mathrm{kWh}_{\mathrm{th}}$ of energy is required to preheat the engine during each start-up cycle (Carbon Trust, 2007), and so houses with larger than average demand for heat $\left(<20 \mathrm{MWh}_{\text {th }}\right.$ per year) were identified as the target market, enabling longer running times and fewer on-off cycles.

Total efficiency is similar to other CHP systems, being $71 \cdot 5 \pm 5 \%$. Electrical as well as thermal efficiency in larger models has also been found to decrease as output water temperature increases, with $\sim 1 \%$ lost per $10^{\circ} \mathrm{C}$ of heating (Kuhn et al., 2007; Thomas, 2008). It is therefore important to maintain low space heating and hot water temperatures.

The low electrical efficiency of Stirling engines has a profound impact on the fundamental benefits of CHP operation. With an average of only $700-1200 \mathrm{kWh}_{\mathrm{e}}$ of electricity generated annually in field-trial systems, the economic return and carbon dioxide reductions are low (Carbon Trust, 2007). Despite these modest savings, manufacturers confidently advertise short payback times for their products: 'as little as 3 years in a typical family home' for the WhisperGen, assuming it only costs $£ 500$ more than the boiler it replaces (E.ON UK, 2006). However, the Carbon Trust estimates that engines currently cost $£ 1500$ more, giving much less attractive payback times of 20 years or more (Carbon Trust, 2007).

\subsubsection{Emissions. Emissions of local air pollutants from} Stirling engines can be comparable to those of a condensing boiler, and are advertised as being ten times lower than for IC engines (Baxi, 2008; Onovwiona and Ugursal, 2006). Exhaust concentrations of carbon monoxide and nitrogen oxide from the SOLO 161 mini-CHP engine (the manufacture of this $9 \mathrm{~kW}$ engine was taken over by Stirling Systems in 2007) are, however, an order of magnitude higher than the EcoPower IC engine, which uses a catalytic converter (Thomas, 2008).

Emissions from the WhisperGen are not well reported, and so are estimated to be similar to the SOLO engine, lying in the range $25-35 \mathrm{mg}$ of nitrogen oxide and $13-18 \mathrm{mg}$ of carbon monoxide per kWh of fuel input (Pehnt et al., 2006). With the low electrical efficiency of the Whispergen, emissions per $\mathrm{kWh}_{\mathrm{e}}$ are likely to be much higher than from the catalytically controlled ECOWILL engine.

3.3.2.4. Durability. Stirling engines are expected to prove more durable than IC engines, as the sealed operating chamber reduces engine wear. Mini-CHP engines can operate for 5000$8000 \mathrm{~h}$ between servicing intervals, and the free-piston engines being introduced are hypothesised to require no mechanical maintenance owing to minimised mechanical contact and wear (Onovwiona and Ugursal, 2006). However, there have been issues with the immature designs currently being demonstrated. In the Carbon Trust field trial, 25\% of the Stirling engines installed suffered a fault that required repair during their first year (Carbon Trust, 2007). System lifetimes have not been widely verified as the technology is still emerging, but 10 years of operation are expected (Onovwiona and Ugursal, 2006).

3.3.3. Fuel cells. Fuel cells operate with a different mechanism to CHP engines, electrochemically converting fuel directly into DC current rather than combusting it. The two principal designs both require precision engineering and exotic materials to provide the required efficiency and durability. Low-temperature polymer electrolyte membrane fuel cells (PEM/PEFC/PEMFC) use hydrated fluoropolymer composites and small, but not negligible quantities of platinum as a catalyst. Extensive work is going towards developing platinum-free PEM cells to reduce material costs and ease the requirements on fuel purity. Solid oxide fuel cells (SOFC) use fragile, $10-100 \mu \mathrm{m}$ thick ceramic composites and chromium alloys that can withstand the 500-900 ${ }^{\circ} \mathrm{C}$ operating temperature (Hawkes et al., 2009).

As with solar PV or batteries, individual cells are connected in series to form what is referred to as a 'stack', giving a higher voltage for converting to AC. Another similarity is the complex relationship between the voltage and current produced, so a system controller is required to select the maximum power point for a given output, and to regulate the supply of fuel, air and water.

Pure hydrogen is required by fuel cells to operate effectively, and so natural gas or LPG is reformed on demand in an integrated fuel processor. Heat generated by the fuel cells and processor is recovered by circulating highly purified water around the cells (for PEMFC) and from high-temperature exhaust gasses (both designs). This provides low heat output $\left(\sim 0 \cdot 6-2 \mathrm{~kW}_{\text {th }}\right.$ per $\left.\mathrm{kW}_{\mathrm{e}}\right)$, so a backup burner is employed to cover peak heat demands.

Operation can be more flexible than for CHP engines, as power output can be changed almost instantaneously, allowing the electrical demand of a house to be followed closely. The low heat output lessens the constraint on running hours during summer. There are, however, more strict constraints on start-up and shutdown, as approximately an hour of pre-heating is required for PEMFC systems incorporating a fuel processor, increasing to $12-24 \mathrm{~h}$ for SOFCs (Ceramic Fuel Cells Limited, 2009; Staffell, 2009a; Toshiba Fuel Cell Power Systems Corporation, 2009). Sophisticated control logic is therefore used to predict when best to operate, and many SOFC systems are run continuously, modulating to minimum power output when there is little or no demand. 
Fuel-cell-based micro-CHP systems are reviewed more thoroughly in other work by the authors (Hawkes et al., 2009).

3.3.3.1. Cost. The most commercially developed systems are PEMFCs from Panasonic, SANYO and Toshiba. Jointly launched under the brand name ENEFARM in May 2009, these are now available to purchase throughout Japan (Osaka Gas, 2009; Tokyo Gas Co., 2009). Several manufacturers including Baxi, Ceres Power, CFCL and Kyocera are developing products that are scheduled to be commercially launched in the early 2010s. These companies are developing high-volume production facilities and have completed initial product testing or field trials with European and Japanese gas suppliers (Baxi Innotech, 2009; Ceres Power, 2009; Dow, 2009; Kyocera Corporation, 2009).

Fuel cells are the most expensive form of micro-CHP at present. There is still limited information on the price of most systems, owing to commercial secrecy and low production volumes. Between 2005 and 2009, the average price of $0 \cdot 75-1 \mathrm{~kW}_{\mathrm{e}}$ ENEFARM systems decreased from $£ 36000$ for early demonstrations to $£ 15500$ at the time of commercial launch (Staffell and Green, 2009). In comparison, leading SOFC demonstration systems from Hexis and Kyocera cost a minimum of $£ 30000$ for 0.7 and $1.0 \mathrm{~kW}_{\mathrm{e}}$ systems (Singhal, 2007; Yamamoto, 2008). It must be remembered that these are pre-commercial designs produced by skilled engineers rather than production lines, so mass production will bring with it substantial cost reductions. However, it is expected that ten years of deployment and cost reduction is required before unsubsidised prices reach $£ 5000$ per $\mathrm{kW}_{\mathrm{e}}$ (Staffell and Green, 2009).

\subsubsection{Efficiency. Fuel cells offer significantly higher} electrical efficiency than CHP engines, which can rival that of modern CCGTs. Their total efficiency is currently lower than engines though, owing to their relative immaturity and difficulties in capturing low-grade waste heat (Hawkes et al., 2009). It is important to differentiate between the efficiency of the fuel cell stack and complete CHP systems, as the fuel processor and other sub-systems reduce the performance of real-world systems by 20-33\% (Hawkes et al., 2009; Staffell, 2009a).

Leading SOFC systems have demonstrated electrical efficiencies as high as $40-50 \%$ HHV when operating on natural gas (Ceramic Fuel Cells Limited, 2009; New Energy Foundation, 2009a; Todo et al., 2008). Fuel processing incurs greater losses in PEMFC systems, and so quoted efficiencies for ENEFARM systems are 31-33\% (Osaka Gas, 2009; Tokyo Gas Co., 2009). European and American systems cannot match the leading Japanese models, with efficiencies for both PEMFC and SOFC being 5-10\% lower than these values (Baxi Innotech, 2009; Singhal, 2007).

Thousands of ENEFARM systems have been trialled in Japanese homes for up to 4 years, demonstrating average efficiencies of 27-31\% electrical, and 68-75\% total (Kimura, 2008; New Energy Foundation, 2009b; Yamada, 2007). Smaller demonstrations of Kyocera SOFC systems in Japan have shown that 35\% electrical and 72\% total efficiency can be achieved in domestic operation (New Energy Foundation, 2008, 2009a).
However as seen in Figure 9, the inflexible operation of microCHP systems meant that much of the generated energy went to waste. Always-on SOFC systems suffered particularly from the limited thermal demand of Japanese homes, again raising the issue of correctly sizing and siting these technologies. These same issues, and a similar loss of performance relative to manufacturers' specifications were reported in the only published field trial of a PEMFC system in a UK house (Staffell, 2009a).

Limited experiments have shown that significantly more energy is required to pre-heat fuel cells than for other micro-CHP technologies, owing to the slower heating rates and greater mass of systems (Arndt, 2007; Staffell, 2009a). As PEMFC systems are run with daily stop-start cycles and are usually located outside, this additional energy input is effectively wasted. Most commercial systems also exhibit lower efficiency at part-load owing to the impact of fuel processing, despite the often cited high part-load efficiency of fuel cell stacks (Hawkes et al., 2009; Staffell, 2009a).

\subsubsection{Emissions. Fuel cells cannot be classed as} zero-emission when operated on natural gas, however they emit negligible quantities of local pollutants as the fuel is processed (usually by steam reforming), rather than combusted in air. The emissions from industrial-CHP systems have been measured by several authors to be just 1-15\% that of enginebased systems (average emissions are $1.6 \mathrm{mg}$ nitrogen oxide and $2.7 \mathrm{mg}$ of carbon monoxide per $\mathrm{kWh}$ fuel input) with emissions of sulfur dioxide, methane other volatile organic compounds (VOCs), and particulates usually below the detection threshold of measurements (Appleby, 1996; Pehnt, 2003; Rooijen, 2006). Emissions from domestic-scale systems should be similar to these larger units, so long as steam reforming is used.

3.3.3.4. Durability. A central focus of current research is in improving the lifetime and reliability to the levels of engines and boilers. Top-performing PEMFC systems have demonstrated 20000 operating hours, equivalent to 5 years of intermittent generation (Homma, 2008; Nishizaki, 2008) and double this is expected from the next generation now being sold (Panasonic Corporation, 2008). As SOFC systems are only beginning to be demonstrated in larger numbers, there are only limited reports of lifetimes beyond 10000-15000 h (Acumentrics, 2008; Mai et al., 2007; Yamamoto, 2008).

Reliability is currently poor, which can be attributed to rapidly evolving system designs and the use of novel components to improve performance. Less than a tenth of the ENEFARM systems being trialled experienced no faults in their first year of operation, with an average of $0 \cdot 8$ breakdowns experienced per year (New Energy Foundation, 2009b; Omata et al., 2007b). The failure rate was halved between 2005 and 2007 as problem components were identified and improved, and it is expected that the commercial models launched in 2008 will fare much better still.

\section{CONCLUSIONS AND DISCUSSION}

The portfolio of technologies reviewed in this paper is very broad; using the single label of 'microgeneration' can be quite misleading when discussing their place in the larger energy 


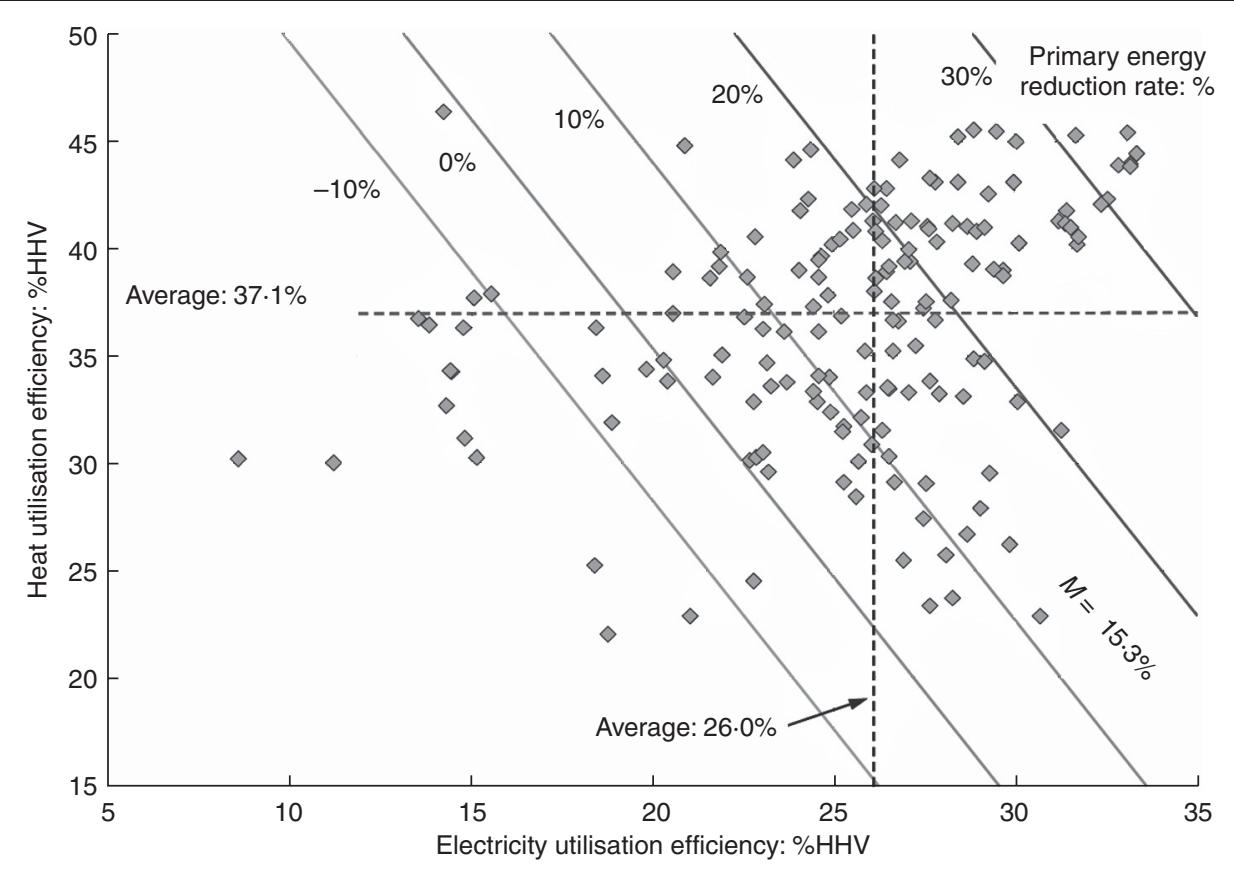

(a)

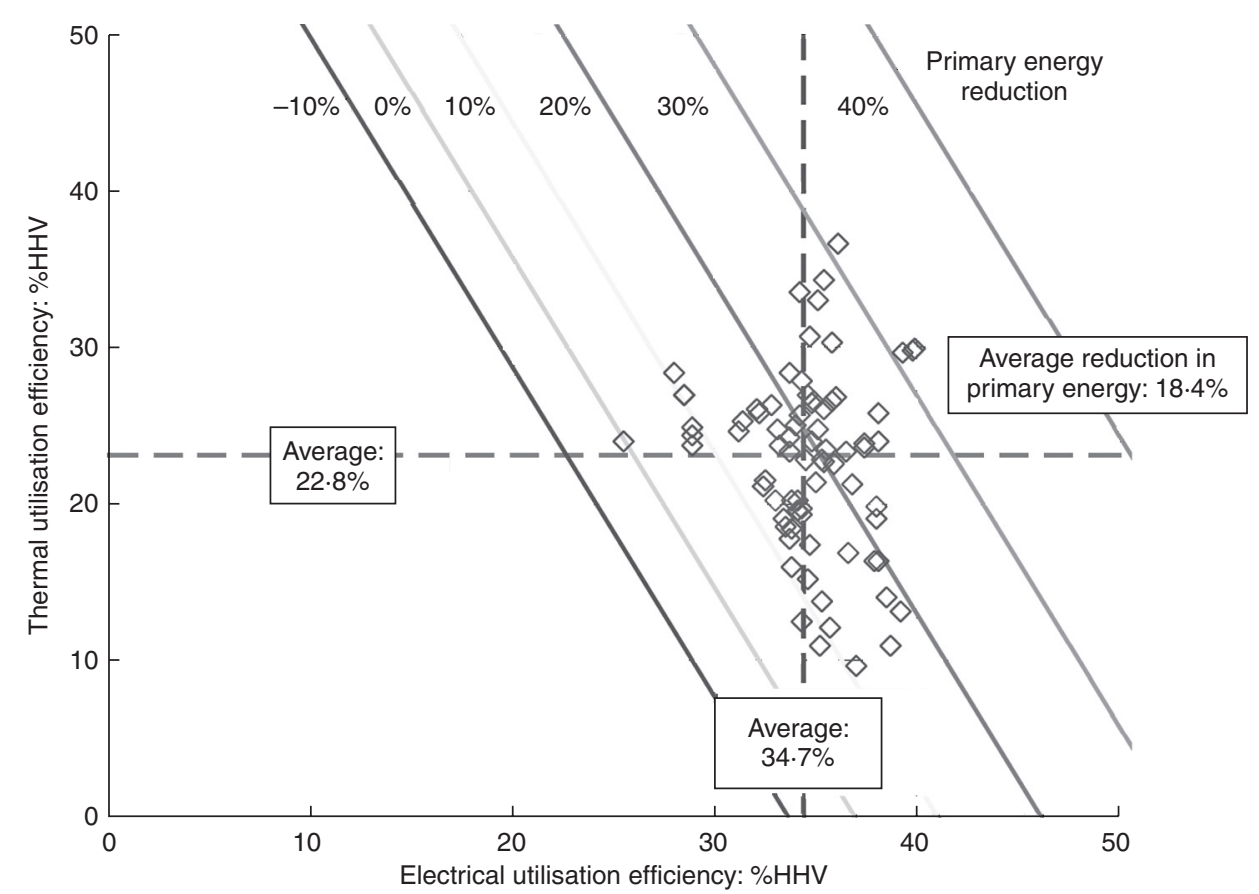

(b)

Figure 9. Plots of the electrical and thermal efficiencies experienced in individual houses using (a) ENEFARM PEMFC systems and (b) Kyocera SOFC systems. Utilisation efficiencies were net of any energy that was not used in the home, meaning that thermal efficiencies were up to a third lower than gross generating efficiency. Taken from Omata et al. (2007a) and New Energy Foundation (2008)

picture. The energy output, efficiency and cost of these technologies varies widely, with devices ranging from meeting the energy requirement of a whole house, to producing a few hundred kWh per year. A summary of the technologies is given in Table 6.

Microgeneration can make a significant contribution to the supply of heat and power and the reduction of carbon dioxide emissions in the residential sector. However, successful deployment relies on matching the right technology to the load requirement of the dwelling. If the renewable resources at a particular location are not suitable, or if a technology is inappropriately installed or sized, there is the potential for an overall increase in carbon dioxide emissions and adverse economics of ownership.

Field trials show that there are many discrepancies between manufacturers' claims and what is actually delivered in terms of efficiency, energy produced, realistic payback times and so on. This may point to the need for better regulation, with the risk of these technologies, or microgeneration as a whole receiving a bad image. 


\begin{tabular}{|c|c|c|c|c|}
\hline & $\begin{array}{l}\text { Typical capacity: } \\
\text { kW }\end{array}$ & Efficiency/COP/annual yield & $\begin{array}{l}\text { Current installed cost: } \\
\qquad £ \times 1000\end{array}$ & $\begin{array}{c}\text { Expected lifetime: } \\
\text { years }\end{array}$ \\
\hline Condensing boiler & $25_{\mathrm{th}}$ & $82-89 \%$ & $1.5-2.5$ & $10-20$ \\
\hline Biomass heater & $<5_{\text {th }}$ & $70-80 \%$ & $2-4$ & $20-30$ \\
\hline Biomass boiler & $10-20_{\mathrm{th}}$ & $80-90 \%$ & $5-15$ & \\
\hline ASHP & $5-15_{\text {th }}$ & $2 \cdot 9-3 \cdot 5$ & $1-6$ & $15-25$ \\
\hline GSHP & & $3 \cdot 9-4 \cdot 8$ & $10-15$ & (up to 50 ) \\
\hline Solar photovoltaic & $1.5 \mathrm{e}$ & $1000-1300 \mathrm{kWh}$ & $6-10$ & $25-50$ \\
\hline Solar thermal & $3_{\mathrm{th}}$ & $800-1700 \mathrm{kWh}$ & $2-8$ & $25+$ \\
\hline Micro-wind & $0 \cdot 6-1 \cdot 2_{e}$ & $\begin{array}{l}50-150 \mathrm{kWh} \text { urban } \\
500-1000 \mathrm{kWh} \text { rural }\end{array}$ & $2+$ & 15 \\
\hline IC engine & $\begin{array}{l}I_{e} \\
3_{\text {th }}\end{array}$ & $\begin{array}{c}20 \%_{\mathrm{e}} \\
75-80 \%_{\text {total }}\end{array}$ & $4-6$ & $10-20$ \\
\hline Stirling engine & $\begin{array}{c}I_{e} \\
5-\mid 3_{\text {th }}\end{array}$ & $\begin{array}{c}4-8 \% \\
75-80 \% \text { total }\end{array}$ & $\begin{array}{c}3 \\
\text { (subsidised) }\end{array}$ & 10 \\
\hline Fuel cell & $\begin{array}{l}0.7-I_{e} \\
0.5-3_{\text {th }}\end{array}$ & $\begin{array}{l}30-35 \% \%_{\text {e }} \\
70-75 \%_{\text {total }}\end{array}$ & $15+$ & $3-10$ \\
\hline
\end{tabular}

It is clear that no other genre of energy generation has such a direct relationship with the user and their environment. This, taken together with the previous points highlights the importance of having a sound understanding of the features of each of these technologies and their current state of development, so that rational decisions can be made as to if, when and where they are applied.

\section{ACKNOWLEDGEMENT}

The authors would like to acknowledge the UK Energy Research Centre (UKERC) for funding the activities of the Microgeneration Group.

\section{REFERENCES}

Acumentrics (2008) Acumentrics fuel cell tops 10,000 operating hours. See http://tinyurl.com/27bjp57 (accessed June 2010).

Aki H (2007) The penetration of micro CHP in residential dwellings in Japan. Proccedings of IEEE Power Engineering Society General Meeting, Tampa, Florida, pp. 1-4.

Allen SR, Hammond GP and McManus MC (2008a) Energy analysis and environmental life cycle assessment of a micro-wind turbine. Proceedings of the Institution of Mechanical Engineers, Part A: Journal of Power and Energy 222(7): 669-684.

Allen SR, Hammond GP and McManus MC (2008b) Prospects for and barriers to domestic micro-generation: a United Kingdom perspective. Applied Energy 85(6): 528-544.

Ampair Microwind (2008) Ampair 600 wind turbine. See http:// tinyurl.com/ykm78zm (accessed January 2008).

Ampair Microwind (2009) Online shop. See http://www.boostenergy.com/ampair/shop.asp (accessed November 2009).

Appleby AJ (1996) Issues in fuel cell commercialization. Journal of Power Sources 58(2): 153-176.

Argiriou A, Klitsikas N, Balaras C and Asimakopoulos D (1997) Active solar space heating of residential buildings in northern Hellas - a case study. Energy and Buildings 26(2): 215-217.

Arndt U (2007) Investigation of a Vaillant Fuel Cell Euro 2 at the Technical University of Munich. In Experimental Investigation of Residential Cogeneration Devices and
Calibration of Annex 42 Models (Beausoleil-Morrison I (ed.)). International Energy Agency, Canada.

Baxi (2008) Baxi micro-CHP: clean and efficient energy for the home. See http://www.baxi.co.uk/docs/

Baxi_microchp_leaflet.pdf (accessed June 2010).

Baxi (2009) Baxi EcoGen. See http://www.baxi.co.uk/baxiecogen (accessed September 2009).

Baxi Innotech (2007) Beta 1.5 Plus Product Brochure. Baxi Innotech, Hamburg.

Baxi Innotech (2009) Gamma 1.0 Product Brochure - A New Perspective. Baxi Innotech, Hamburg.

Baxi-SenerTec UK (2006) DACHS - Features. See http:// tinyurl.com/yoxaf3 (accessed August 2008).

Bean S (2008) What a years supply of wood looks like? See http://tinyurl.com/n7mwkb (accessed January 2009).

Beausoleil-Morrison I (2007) Experimental Investigation of Residential Cogeneration Devices and Calibration of Annex 42 Models. International Energy Agency, Paris. A report of subtask B of FC+COGEN-SIM.

Bergman N and Jardine C (2009) Power from the people: domestic microgeneration and the lower carbon buildings programme. Environmental Change Institute, Oxford.

Bergman N, Hawkes A, Brett DJL et al. (2009) UK Microgeneration. Part I: policy and behavioural aspects. Proceedings of the Institution of Civil Engineers, Energy 162(1): 23-36.

BERR (Department for Business Enterprise and Regulatory Reform) (2009a) Householders - low carbon buildings programme. See http://tinyurl.com/37agl2h (accessed February 2009).

BERR (2009b) Low carbon buildings programme: biomass. See http://tinyurl.com/3xcytq5 (accessed February 2009).

BERR (2009c) Low carbon buildings programme: wind turbines. See http://tinyurl.com/336zgak (accessed February 2009).

Biomass Energy Centre (2008) Information sheet 9: domestic heating with logs. Forestry Commission, Bristol.

Biomass Energy Centre (2009) Typical calorific values of fuels. See http://tinyurl.com/6773f2 (accessed January 2009).

Braun AE (2009) PV Grid Parity Not as Close as Hoped? See http://tinyurl.com/yeyl3v5 (accessed December 2009). 
Brian Dunlop Associates (2008) Ashenden wind turbine trial: phase I results. See http://www.elephantandcastle.org.uk/ ?f=getfile\&tfileid=1560 (accessed June 2010).

Bridges A (2000) NASA to Contact Oldest Spacecraft on 35th Anniversary. See http://tinyurl.com/nmpgfe (accessed February 2009).

Brinkley M (2006) Eco bollocks award: the Windsave WS1000. Housebuilder's Update. See http://tinyurl.com/5soq12 (accessed June 2010).

British AirCon (2010) Split Air Conditioning. See http:// www.britishaircon.com/Split-Air-Conditioning.html (accessed June 2010).

BWEA (British Wind Energy Association) (2008a) Govt gives green light to micro wind. See http://tinyurl.com/lwtbf7 (accessed March 2008).

BWEA (2008b) Small wind systems UK market report 2008. See http://tinyurl.com/yjycj77 (accessed June 2010).

BWEA (2009a) Location, location: proper turbine placement key to viability. See http://tinyurl.com/yhlrtu5 (accessed January 2009).

BWEA (2009b) UK wind speed database. See http:// www.bwea.com/noabl/ (accessed August 2009).

Caird S, Roy R and Herring H (2008) Improving the energy performance of UK households: results from surveys of consumer adoption and use of low- and zero-carbon technologies. Energy Efficiency 1(2): 149-166.

Canmet Energy Technology Centre (2002) Commercial earth energy systems: a buyer's guide. Canmet Energy Technology Centre, Ottowa.

Carbon Trust (2007) Micro-CHP accelerator: interim report. See http://tinyurl.com/3ahxkqw (accessed November 2007).

Ceramic Fuel Cells Limited (2009) BlueGEN: Modular Generator - Power + Heat. See http://tinyurl.com/paxjh4 (accessed August 2009).

Ceres Power (2009) British Gas confirms Alpha CHP product testing successfully completed. See http://tinyurl.com/ mxst35 (accessed June 2009).

Clark P, Gallani M, Hollis D, Thomson D and Wilson C (2008) Urban wind energy research project part 2 - estimating the wind energy resource. Small-scale Wind Energy. Carbon Trust, Witney, Technical report.

Croxford B and Scott K (2006) Can PV or solar thermal be cost effective ways of reducing $\mathrm{CO}_{2}$ emissions for residential buildings? In Solar 2006: Renewable Energy, Key to Climate Recovery (Cambell-Howe R (ed.)). American Solar Energy Society, Denver. See http://eprints.ucl.ac.uk/2642/ (accessed June 2010).

DECC (2009) Consultation on Renewable Electricity Financial Incentives. Department of Energy and Climate Change, London, URN: 09D/677.

Defra (Department for Environment, Food and Rural Affairs) (2008a) Boiler Efficiency Database. See http:// www.sedbuk.com/ (accessed May 2009).

Defra (2008b) Explanatory memorandum to the electricity and gas (carbon emissions reduction). Department for Environment, Food and Rural Affairs, London, Order No. 188.

Dow B (2009) FY09 - Preliminary Final Results. See http:// tinyurl.com/kosafa (accessed August 2009).

DTI (Department of Trade and Industry) (2007) Domestic Photovoltaic Field Trial Detailed Data Files. DTI, London, URN: 07/1327DVD. See http://tinyurl.com/kvcb83 (accessed June 2010).
Ekins-Daukes N (2009) Solar energy for heat and electricity: the potential for mitigating climate change. Grantham Institute for Climate Change, briefing paper No 1. See http:// tinyurl.com/146qpl (accessed June 2010).

Element Energy (2008) The growth potential for microgeneration in England, Wales and Scotland. BERR, London. See http://www.berr.gov.uk/files/file46003.pdf (accessed June 2010).

Elsayed MA, Matthews R and Mortimer ND (2003) Carbon and Energy Balances for a Range of Biofuels Options. Department of Trade and Industry, London. See http://www.berr.gov.uk/files/file14925.pdf (accessed June 2010).

Enatec Micro-cogen B.V. (2007) Enatec micro-cogen signs agreement with Bosch Thermotechnik, MTS and Rinnai. Press release dated 12 September 2007.

Encraft (2007) The practical realities of microwind power. Warwick Wind Trials Open Day. See http://tinyurl.com/ besloa (accessed June 2010).

Encraft (2009) Warwick Wind Trials - Final Report. Encraft, Leamington Spa.

Energie-Cités (2000) Micro CHP technologies: Frankfurt. See http://www.energie-cites.eu/db/frankfurt-ammain_132_en.pdf (accessed June 2008).

Energy Saving Trust (2000) Heat Pumps in the UK - a Monitoring Report (GIR72). Energy Saving Trust, London.

Energy Saving Trust (2003) Energy Efficiency Best Practice in Housing: Domestic Condensing Boilers - 'The Benefits and the Myths'. Energy Saving Trust, London. See http://www. west-norfolk.gov.uk/pdf/CE52.pdf (accessed June 2010).

Energy Saving Trust (2004) Energy Efficiency Best Practice in Housing: Domestic Ground Source Heat Pumps: Design and Installation of Closed-Loop Systems. Energy Saving Trust, London. See http://tinyurl.com/yj246ld (accessed June 2010).

Energy Saving Trust (2005) Potential for Microgeneration Study and Analysis. Department for Business Enterprise and Regulatory Reform, London. See http://www.berr.gov.uk/ files/file27558.pdf (accessed June 2010).

Energy Saving Trust (2008) Measurement of Domestic Hot Water Consumption in Dwellings. Defra, London. See http:// tinyurl.com/lrewoh (accessed June 2010).

Energy Saving Trust (2009) Location, Location, Location: Domestic Small-Scale Wind Field Trial Report. See http:// tinyurl.com/lmh8r4 (accessed June 2010).

EnergyWatch (2008) Finding the Right Deal For You - Consumer Focus. See http://tinyurl.com/mkeqah (accessed October 2008).

Entchev E, Gusdorf J, Swinton M et al. (2004) Micro-generation technology assessment for housing technology. Energy and Buildings 36(9): 925-931.

E.ON UK (2006) Performance of Whispergen micro CHP in UK homes. See http://tinyurl.com/yzqaav2.

E.ON UK (2009) WhisperGen. See http://tinyurl.com/lmqgfj (accessed September 2009).

European Commission and Intelligent Energy (2007) Catalogue of Urban Wind Turbine Manufacturers. See http:// zeeuwind.nl/uploadedfiles/catalogue_v2.pdf (accessed June 2010).

Fisher J, Jessop C, McGuire K and Waddelove A (2008) A Review of Microgeneration and Renewable Energy Technologies. NHBC Foundation and BRE Press, Watford. 
Forward D, Perry A, Swainson M, Davies N and Elmes S (2008) Viridian Solar - Clearline Solar Thermal Field Trial. Building Research Establishment, London, Report number 225314. See http://tinyurl.com/lreywe (accessed June 2010).

Fronius (2009) USA Premium 10-Year Warranty and 15-Year Extended Warranty. See http://tinyurl.com/kmedab (accessed June 2009).

Future Energy Solutions (2006) Renewable Heat and Heat from Combined Heat and Power Plants - Study and Analysis Report. AEA Technology, Didcot, UK.

Gottschalg R, Infield DG and Kearney MJ (2003) Experimental study of variations of the solar spectrum of relevance to thin film solar cells. Solar Energy Materials and Solar Cells 79(4): 527-537.

Graham-Harrison E (2006) Energy-hungry China warms to solar water heaters (5 June 2006). Reuters.

Green Consumer Guide (2005) How Much Does a WhisperGen Cost? See http://tinyurl.com/f7yec (accessed June 2008).

Green MA, Emery K, Hishikawa Y and Warta W (2009) Short communication solar cell efficiency tables (version 33). Progress in Photovoltaics: Research and Applications 17(1): 85-94.

Green Warmth (2007) Biomass boilers. See http:// www.greenwarmth.co.uk/biomassboilers.asp (accessed November 2008).

Gummert G (2008) Baxi Group: delivering the spark. Gas Industry micro-CHP Workshop. Paris. See http:// tinyurl.com/17559q (accessed June 2010).

Guntamatic (2007) Biostar Flex Product Brochure. Georg Fischer Group, Austria.

Harrison J (2008a) Stirling Engine. See http://www.microchap. info/stirling_engine.htm (accessed June 2008).

Harrison J (2008b) What is microgeneration? Proceedings of Claverton Energy Group Conference, Bath. See http:// www.claverton-energy.com/what-is-microgeneration.html (accessed June 2010).

Harrogate Borough Council (2007) Results of the Ground Source Heat Pump Trial at Copt Hewick, Harrogate, North Yorkshire. Harrogate Borough Council, Harrogate.

Hawkes AD and Brandon NP (2009) Carbon dioxide performance assessment for micro combined heat and power. Touch Briefings: Modern Energy 1(1): 17-19.

Hawkes A, Staffell I, Brett D and Brandon N (2009) Fuel cells for micro-combined heat and power generation. Energy and Environmental Science 2(7): 729-744.

Health and Safety Commission (2000) Legionnaires Disease: the Control of Legionella Bacteria in Water Systems; Approved Code of Practice and Guidance. HSE Books, London.

Hill F (2009) Achievement of Dividends from Solar Water Heating. Architecture: Advanced Energy and Environmental Studies. MSc thesis, Centre for Alternative Technology, Machynlleth.

Hokkaido Gas Co. (2009) (ECOWILL home gas appliances). See http://eco.hokkaido-gas.co.jp/ecowill/, in Japanese (accessed June 2009).

Homma T (2008) The latest fuel cell news in Japan. See http:// www.fcdic.com/eng/news/200807.html\#3 (accessed October 2008).

Honda Motor Co. (2004) Honda's compact household cogeneration unit awarded 2004 prize for natural gas industry innovation. See http://world.honda.com/news/ 2004/c041020.html (accessed August 2007).
Honda Motor Co. (2007) Honda's compact household cogeneration unit achieves cumulative sales of 50,000 units in Japan. See http://tinyurl.com/ykfk95s.

Horio M, Suri A, Asahara J, Sagawa S and Aida C (2009) Development of biomass charcoal combustion heater for household utilization. Industrial and Engineering Chemistry Research 48(1): 361-372.

Ida H (2008) Optimization of Japanese heat pump systems in the moderate climate region. Proceedings of the 9th IEA Heat Pump Conference, Zürich. See http://tinyurl.com/ykl2dre (accessed June 2010).

Ilex Energy Consulting (2005) Metering, settlement, and export reward: options for micro-generation. DTI, London, URN: 05/573. See http://tinyurl.com/ylygzzn (accessed June 2010).

Inman P (2005a) How reliable are new boilers? The Guardian, 9 April. Manchester, UK. See http://tinyurl.com/2kfsb9 (accessed April 2005).

Inman P (2005b) The new boiler that's causing a heated row. The Guardian. Manchester, UK. See http://tinyurl.com/ 9rjjbb (accessed April 2005).

Ireland D, Claridge J and Pow R (2006) Woodfuel Meets the Challenge. Forestry Commission, Bristol.

Jakob M (2008) The use of new technologies and innovations successful deployment of energy-efficiency in buildings. European Sustainable Energy Week Conference, Brussels.

Jardine CN and Lane K (2002) PV-compare: relative performance of photovoltaic technologies in northern and southern Europe. Proceedings of PV in Europe Conference and Exhibition, Rome, Italy.

Jardine CN and Lane K (2003) Photovoltaics in the UK: a guide for new consumers. ECI, Oxford, Report 27.

Jowit J (2009) Many home turbines fall short of claims, warns study. The Guardian, 13 January.

Kayahara Y (2002) The Development of $1 \mathrm{~kW}$ residential gas engine cogeneration system. Energy and Resources 23(3): $173-176$.

Kimura T (2008) Results of the residential fuel cell extensive demonstration project in Japan. Proceedings of the Fuel Cell Seminar and Exposition, Phoenix, Arizona. See http:// tinyurl.com/nuqqg4 (accessed June 2010).

King D (2004) Performance degradation rates in commercial modules. Proceedings of the DEO Solar Program Review Meeting, Denver, USA.

Kuhn V, Klemes J and Bulatov I (2007) Micro-CHP: overview of selected technologies, products and field test results. The 10th Conference on Process Integration, Modelling and Optimisation for Energy Saving and Pollution Reduction, Ischia, Italy. See http://tinyurl.com/chze34 (accessed June 2010).

Kuhn V, Klemes J and Bulatov I (2008) MicroCHP: overview of selected technologies, products and field test results. Applied Thermal Engineering 28(16): 2039-2048.

Kyocera Corporation (2009) Osaka Gas, Kyocera, Toyota and Aisin announce agreement on co-development of solid oxie fuel cell (SOFC) cogeneration system for residential use. See http://global.kyocera.com/news/2009/0508_qazx.html (accessed June 2009).

Laue HJ (2002) Regional report Europe: 'heat pumps - status and trends'. International Journal of Refrigeration 25(4): 414-420.

Le Feuvre P (2007) An Investigation into Ground Source Heat Pump Technology, its UK Market and Best Practice in System Design. MSc thesis, Strathclyde University. 
Lorenz P, Pinner D and Seitz T (2008) The economics of solar power. The McKinsey Quarterly, June. See http:// www.mckinsey.com/clientservice/ccsi/pdf/ economics_of_solar.pdf (accessed June 2010).

Mai A, Sfeir J, Iwanschitz B, Nerlich V and Schuler A (2007) Status of SOFC stack and system development at Hexis. Proceedings of the Fuel Cell Seminar and Exposition, San Antonio, Texas. See http://tinyurl.com/movc5f (accessed June 2010).

Martin C and Watson M (2001) Side by Side Testing of Eight Solar Water Heating Systems. DTI, London, URN 01/1292.

Met Office (2008) Climate indicators. See http://tinyurl.com/ yfk4ybe (accessed May 2009).

Miara M (2008) Performance/optimization of state-of-the art residential heat pump. The 9th IEA Heat Pump Conference, Zürich. http://tinyurl.com/yjyoecr (accessed June 2010)

Micropower Council (2007) Micropower in the UK - State of the Nation and Remaining Challenges. Micropower Council, Solihull, UK.

Mitsubishi Electric (2008) Ecodan advanced heating technology. See http://www.mitsubishi-aircon.co.uk/ displayfile.asp?id=94081 (accessed June 2010).

Munzinger M, Crick F, Dayan EJ, Pearsall N and Martin C (2006) Domestic Photovoltaic Field Trials. BRE and DTI, London, Final technical report, URN: 06/2218. See http:// www.berr.gov.uk/files/file36660.pdf (accessed June 2010).

MVV Consulting (2007) Heating and Cooling from Renewable Energies: Costs of National Policies and Administrative Barriers. European Commission, Brussels. See http:// tinyurl.com/2waetvm (accessed June 2010).

National House Building Confederation Foundation (2008) $A$ Review of Microgeneration and Renewable Energy Technologies. IHS BRE Press, London.

National Renewable Energy Laboratory (2004) PV FAQs. See http://www.nrel.gov/docs/fy04osti/35489.pdf (accessed May 2008).

Navigant Consulting (2006) A review of PV inverter technology cost and performance projections. NREL. See http:// www.nrel.gov/pv/pdfs/38771.pdf (accessed June 2010).

Navitron (2008) Navitron: Heat Pumps. See http:// www.navitron.org.uk/page.php?52 (accessed June 2009).

New Energy Foundation (2008) Overview of solid oxide fuel cell demonstrations for 2007. See http://sofc.nef.or.jp/topics/ pdf/20080527_01.pdf, in Japanese (accessed November 2008).

New Energy Foundation (2009a) (Solid oxide fuel cell empirical research). See http://sofc.nef.or.jp/topics/pdf/ 2009_sofc_houkoku.pdf, in Japanese (accessed July 2009).

New Energy Foundation (2009b) Report data from the large scale residential fuel cell demonstration project in 2008. See http://happyfc.nef.or.jp/pdf/20fc.pdf, in Japanese (accessed April 2009).

Nishizaki K (2008) The Japanese experience in micro CHP for residential use. Gas Industry Micro CHP Workshop, Paris. See http://www.marcogaz.org/events/events_text4.htm (accessed July 2009).

Northrop A (2009) Windsave founder blames legislation delays for administration. Business7, Glasgow. See http:// tinyurl.com/r6qefv (accessed September 2009).

NTB (2008) Prüfresultate geprüfter Wärmepumpen (Results of certified heat pump testing). See http://www.ntb.ch/ 3895.html, in German (accessed June 2008).
Nu-Heat (2007) Model 1140 brochure. See http://tinyurl.com/ 5xt9wt (accessed February 2009).

Omata T, Kimura T, Yamamoto Y and Nishikawa S (2007a) Current status of the large-scale stationary fuel cell demonstration project in Japan. Fuel Cell Seminar and Exposition, San Antonio, USA.

Omata T, Kimura T, Yamamoto Y and Nishikawa S (2007b) Current status of the large-scale stationary fuel cell demonstration project in Japan. Proceedings of the 10th Grove Fuel Cell Symposium, London.

Onovwiona HI and Ugursal VI (2006) Residential cogeneration systems: review of the current technology. Renewable and Sustainable Energy Reviews 10(5): 389-431.

Orr G, Lelyveld T and Burton S (2009) Insitu Monitoring of Efficiencies of Condensing Boilers and use of Secondary Heating. Department of Energy and Climate Change, London. See http://tinyurl.com/mdt2bq (accessed September 2009).

Osaka Gas (2009) ENE-FARM product information. See http:// www.ene-farm.info/en/products/ (accessed August 2009).

Osaka Gas Co. (2009) (g-life/ECOWILL/choice of line-up). See http://g-life.osakagas.co.jp/3-cogeneration/1-lineup.html, in Japanese (accessed June 2009).

Osaka Gas Corporation (2002) Development of $1 \mathrm{~kW}$ residential gas engine cogeneration system. See http://www.dgc.dk/ nyhedsservice/ecowill.ppt (accessed June 2008).

Panasonic Corporation (2008) Panasonic develops new fuel cell cogeneration system for home use. See http://tinyurl.com/ $5 \mathrm{fk} 325$ (accessed June 2009).

Peacock AD, Jenkins D, Ahadzi M, Berry A and Turan S (2008) Micro wind turbines in the UK domestic sector. Energy and Buildings 40(7): 1324-1333.

Pehnt M (2003) Life-cycle analysis of fuel cell system components. In Handbook of Fuel Cells - Fundamentals, Technology and Applications (Vielstich W, Lamm A and Gasteiger HA (eds)). Wiley, Chichester.

Pehnt M, Cames M, Fischer C et al. (2006) Micro Cogeneration: Towards Decentralized Energy Systems. Springer, Berlin.

Pellets@LAS (2009) Pellet market database. See http:// www.pelletcentre.info/cms/site.aspx?p=7204 (accessed January 2009).

Perlin J (2005) Solar evolution: the history of solar energy. See http://tinyurl.com/ygyupj6 (accessed June 2008).

Phillips R, Blackmore P, Anderson J et al. (2007) Micro-wind Turbines in Urban Environments - An Assessment. Building Research Establishment, London.

Practical Action (2006) Solar cooking and health. See http:// tinyurl.com/ye4ewr4 (accessed June 2008).

Praetorius B and Schneider L (2006) Micro cogeneration: towards a decentralized and sustainable german energy system? The 29th IAEE International Conference, Potsdam. See http://www.oeko.de/oekodoc/579/2006-136-en.pdf (accessed February 2009).

REN21 (2009) Renewables global status report: 2009 Update. Paris. See http://tinyurl.com/yhflbp8.

Rock Energy (2007) Ecopower technical specifications. See http://tinyurl.com/nun5r7 (accessed June 2008).

Rooijen JV (2006) A Life Cycle Assessment of the Purecell Stationary Fuel Cell System: Providing a Guide for Environmental Improvement. Industrial Ecology. MSc thesis. Leiden University. See http://tinyurl.com/yk7tuvc (accessed June 2010). 
Ross D (1990) Pilot Study of Commercial Water-Loop Heat Pump Compressor Life. PRA Inc. Reston, VA, USA.

SANYO (2009) SANYO develops HIT solar cells with world's highest energy conversion efficiency of 23.0\%. See http:// tinyurl.com/p6klgx (accessed August 2009).

Senertec (2002) Heat and Power from One Unit. Baxi-SenerTec, Birmingham, UK.

Senertec (2008) Dachs: Europe’s Biggest Selling Combined Heat and Power Unit. Baxi-SenerTec, Birmingham, UK.

Senertec (2009) Der Dachs - Technische Daten (The Dachs Technical Data). See http://tinyurl.com/lxopzr, in German (accessed June 2009).

Singhal SC (2007) Innovative solid oxide fuel cell systems for small scale power generation. Proceedings of the 10th Grove Fuel Cell Symposium, London.

Solar4U Ltd (2009) DIY solar panel kits and evacuated solar tubes trade shop. See http://www.heatmyhome.co.uk/ survey/diy-quote.php (accessed February 2009).

Solarbuzz (2009) Solar photovoltaic, PV module, panel prices. See http://solarbuzz.com/Moduleprices.htm (accessed December 2009).

SolarFocus GmbH (2008a) Log Wood + pellets: Therminator II, The Combi Boiler. Solarfocus GmbH, Steyr, Austria.

SolarFocus GmbH (2008b) Solar Technology Product Brochure. Solarfocus GmbH, Steyr, Austria.

South West of England Regional Development Agency (2008) Biomass case study: The Science Museum and Library, at the Old Wroughton Airfield, near Swindon. See www.knowledgewest.org.uk/displayEntry.asp?URN=41 (accessed February 2009).

Staffell I (2008) Purchase cost of condensing boilers in the UK. See http://wogone.com/iq/purchase_cost_of_condensing_ boilers_in_the_uk.pdf (accessed July 2008).

Staffell I (2009a) Fuel Cells for Domestic Heat and Power: Are They Worth It? PhD thesis, University of Birmingham.

Staffell I (2009b) A review of domestic heat pump coefficient of performance. See http://wogone.com/iq/ review_of_domestic_heat_pump_cop.pdf (accessed April 2009).

Staffell I and Green RJ (2009) Estimating future prices for stationary fuel cells with empirically derived learning curves. International Journal of Hydrogen Energy 34(14): 5617-5628.

Streicher E, Heidemann W and Müller-Steinhagen H (2004) Energy payback time: a key number for the assessment of thermal solar systems. EuroSun2004, Freiburg. See http:// tinyurl.com/ya9htgg (accessed December 2009).

Šúri M, Huld TA, Dunlop ED and Ossenbrink HA (2007) Potential of solar electricity generation in the European Union member states and candidate countries. Solar Energy 81(10): 1295-1305. See http://re.jrc.ec.europa.eu/pvgis.

Tang Y, Raghuraman B, Kuitche J et al. (2006) An evaluation of $27+$ years old photovoltaic modules operated in a hotdesert climatic condition. See http://ieeexplore.ieee.org/iel5/ 4059527/4059868/04060095.pdf (accessed February 2009).

Teekaram A (2005) Installation and monitoring of a Dachs Mini CHP unit at BSRIA. See http://tinyurl.com/4ubazb (accessed June 2008).

The Chartered Institute of Building (2008) How Heat Pump Technology will Reduce your Carbon Footprint. CIOB, London. See http://www.ciob.org.uk/news/view/1691 (accessed January 2009).
The Energy Monitoring Company Ltd (2001) Analysis of Performance Data from Four Active Solar Water Heating Installations. DTI, London, URN 01/781.

The National Energy Foundation (2008) The log pile website. See http://www.nef.org.uk/logpile/pellets/cost.htm (accessed January 2009).

Thomas B (2008) Benchmark testing of micro-CHP units. Applied Thermal Engineering 28(16): 2049-2054.

Todo Y, Ishikawa H, Uematsu H et al. (2008) Development of solid oxide fuel cells at NGK Spark Plug Co. Ltd. Proceedings of the Fuel Cell Seminar and Exposition, Phoenix, Arizona. See http://tinyurl.com/n3c36e (accessed February 2009).

Tokyo Gas Co. (2008) (My home power generation: ECOWILL: line-up of gas apparatus). See http://home.tokyo-gas.co.jp/ ecowill/ (in Japanese) (accessed June 2009).

Tokyo Gas Co. (2009) (My home power generation: ENEFARM: line-up of gas apparatus). See http://home.tokyo-gas.co.jp/ enefarm/enefarm07_01.html (in Japanese) (accessed August 2009).

Toshiba Fuel Cell Power Systems Corporation (2009) (ENEFARM Specifications). See http://www.toshiba.co.jp/product/fc/ products/pdf/catalog5.pdf, in Japanese (accessed August 2009).

Treehugger (2007a) Honda and climate energy team up with Freewatt. See http://www.treehugger.com/files/2007/04/ honda_and_clima.php (accessed June 2008).

Treehugger (2007b) Senertec Dachs: a 90\% efficient power plant for your home. See http://www.treehugger.com/files/ 2007/03/senertec_dachs.php (accessed June 2008).

Utley JI and Shorrock LD (2006) Domestic Energy Fact File. Building Research Establishment, London. See http:// projects.bre.co.uk/factfile/TenureFactFile2006.pdf (accessed June 2006).

Vaughan A (2009) High street quietly ends fling with microgeneration. The Guardian, Manchester, UK, 2 February.

Veitch DCG and Mahkamov K (2009) Assessment of economical and ecological benefits from deployment of a domestic combined heat and power unit based on its experimental performance. Proceedings of IMechE Part A: Journal of Power and Energy 223(7): 783-798.

Vezzini A (2004) Micro-cogeneration: development of the ecopower micro-CHP. See http://pelincec.isep.pw.edu.pl/ doc/vezzini.pdf (accessed June 2008).

Viessmann (2002) Heat pump systems technical guide. Vitotec technical guide folder, register 4.

Viessmann (2007) High efficiency boilers. See http:// www.viessmann.co.uk/downloads/CondensingBoilers.pdf (accessed June 2008).

Watson J, Sauter R, Bahaj B et al. (2008) Domestic microgeneration: economic, regulatory and policy issues for the UK. Energy Policy 36(8): 3095-3106.

Watson SJ, Infield DG and Harding MR (2007) Predicting the yield of micro-wind turbines in the roof-top urban environment. European Wind Conference, Milan.

Wharf Heating and Plumbing Supplies (2008) Air source heat pump. See http://www.wharfplumbing.co.uk/ air_source_heat_pump.htm (accessed June 2009).

Which? (2007) Which? reviews: cost-effective and reliable boilers. See http://www.which.co.uk/reviews/boilers (accessed June 2008). 
Whisper Tech (2003) AC WhisperGen system - product specification. See http://energysavingnow.com/plugin/ ACmk4Specification.pdf (accessed August 2009).

Whisper Tech (2004) Whisper Tech signs $\$ 300$ million agreement. See http://mkv.dgc.dk/Nyhedsservice/WhispergenNZUK.pdf (accessed December 2009).

Whisper Tech (2008a) Manuel de l'utilisateur et specifications techniques (User manual and technical specifications). See http://tinyurl.com/yfm5sqr (accessed November 2009).

Whisper Tech (2008b) Mondragón Corporación Cooperativa and Meridian Energy announce Joint Venture for manufacture of WhisperGen microCHP system. See http://tinyurl.com/ y93wqnu (accessed December 2009).

Wilcox C (2004) Chapnet Micro-CHP: the technology takes off. See http://www.chp-research.com/Downloadables/ Chris\%20Wilcox.pdf (accessed February 2009).

Williams SR, Betts TR, Vorasayan P, Gottschalg R and Infield DG (2005) Actual PV module performance including spectral losses in the UK. Proceedings of the Photovoltaic Specialists Conference. Conference Record of the 31 st IEEE.

Windsave (2009) Cost. See http://www.windsave.com/Costs, \%20Grants\%20\&\%20Payback (accessed February 2009).

Wohlgemuth JH, Cunningham DW, Nguyen AM and Miller J (2005) Long term reliability of PV modules. BP Solar
International. See http://tinyurl.com/dybedx (accessed February 2009).

Woude RVD, Haaken ET, Zutt S, Vriesema B and Beckers G (2004) Intermediate results of the Enatec Micro cogeneration system field trials. Proceedings of the International Stirling Forum, Osnabrück. See http:// tinyurl.com/ycnb7cw (accessed December 2009).

Yamada Y (2007) Performance of residential FC CHP LIFUEL in actual and daily use for years. Proceedings of the 10th Grove Fuel Cell Symposium, London.

Yamamoto A (2008) Activities toward commercialization of fuel cell/hydrogen technology in Japan. Fuel Cell Seminar and Exposition, Phoenix, Arizona.

Yanmar (2009) Cogeneration packages lineup. See http:// www.yanmar.co.jp/en/energy/cogeneration/lineup.html (accessed November 2009).

Zeller A (2007) Heat pumps for private residential buildings. Proceedings of Annex 32 Meeting, Kyoto, Japan. See http:// tinyurl.com/yavqnq7 (accessed November 2009).

Zinßer B, Makrides G, Schmitt W, Georghiou GE and Werner JH (2007) Annual energy yield of 13 photovoltaic technologies in Germany and in Cyprus. Proceedings of the 22nd European Photovoltaic Solar Energy Conference, Milan.

\section{What do you think?}

To discuss this paper, please email up to 500 words to the editor at journals@ice.org.uk. Your contribution will be forwarded to the author(s) for a reply and, if considered appropriate by the editorial panel, will be published as a discussion in a future issue of the journal.

Proceedings journals rely entirely on contributions sent in by civil engineering professionals, academics and students. Papers should be 2000-5000 words long (briefing papers should be 1000-2000 words long), with adequate illustrations and references. You can submit your paper online via www.icevirtuallibrary.com/content/journals, where you will also find detailed author guidelines. 